\title{
Palms of controversies Oil palm and development challenges
}

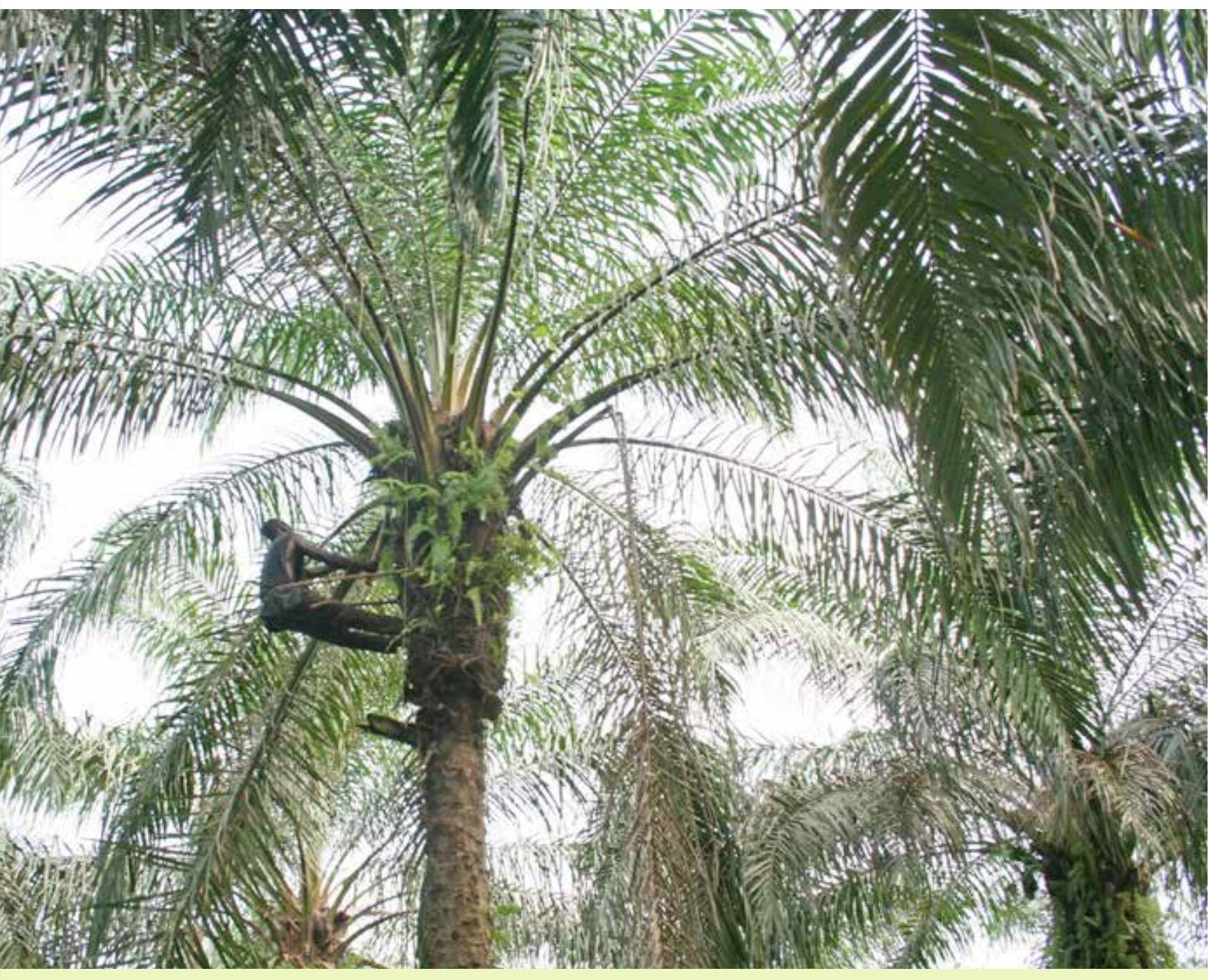

Alain Rival

Patrice Levang 


\section{Palms of controversies Oil palm and development challenges}

Alain Rival

CIRAD

Patrice Levang

IRD / CIFOR 
(C) 2014 Center for International Forestry Research

Content in this publication is licensed under a Creative Commons Attribution-NonCommercialNoDerivs 3.0 Unported License http://creativecommons.org/licenses/by-nc-nd/3.0/

Rival A and Levang P. 2014. Palms of controversies: Oil palm and development challenges. Bogor, Indonesia: CIFOR.

Translated from Rival A and Levang P. 2013. La palme des controverses: Palmier à huile et enjeux de développement. Versailles, France: Éditions Quæ.

ISBN 978-602-1504-41-3

Photo by Alain Rival/CIRAD.

CIFOR

JI. CIFOR, Situ Gede

Bogor Barat 16115

Indonesia

$\mathrm{T}+62$ (251) 8622-622

$F+62$ (251) 8622-100

E cifor@cgiar.org

cifor.org

We would like to thank CIRAD and IRD as well as all donors who supported this research through their contributions to the CGIAR Fund. For a list of Fund donors please see: https://www.cgiarfund.org/ FundDonors

Any views expressed in this book are those of the authors. They do not necessarily represent the views of CIFOR, the editors, the authors' institutions, the financial sponsors or the reviewers. 


\section{Table of contents}

Acknowledgement v v

Introduction 1

Strengths and weaknesses of a unique oil crop 5

Past and future expansion $\quad 5$

A natural oil machine $\quad 7$

A global sector, sustainably rooted in the South 9

$\begin{array}{lr}\text { A versatile crop } & 10\end{array}$

$\begin{array}{ll}\text { Key physical and chemical properties } & 10\end{array}$

$\begin{array}{ll}\text { A flexible species } & 10\end{array}$

$\begin{array}{ll}\text { Fragile coexistence in the tropics } & 11\end{array}$

$\begin{array}{ll}\text { Who really benefits from oil palm cultivation? } & 13\end{array}$

$\begin{array}{ll}\text { The oil palm, miracle or curse? } & 13\end{array}$

$\begin{array}{ll}\text { Palm oil as a forest product } & 13\end{array}$

$\begin{array}{ll}\text { Palm oil exports take off } & 14\end{array}$

$\begin{array}{ll}\text { The arrival of colonial plantations } & 15\end{array}$

$\begin{array}{ll}\text { Stagnation in Africa, boom in Southeast Asia } & 16\end{array}$

$\begin{array}{ll}\text { A development steered by the processing industry } & 17\end{array}$

$\begin{array}{ll}\text { Enter Indonesia } & 18\end{array}$

The oil palm, a good or bad business for local people? 20

$\begin{array}{ll}\text { The oil palm as a real driver of development } & 21\end{array}$

Good for some, bad for others $\quad 22$

Conflicts provoked by the oil palm 23

$\begin{array}{ll}\text { Can palm oil be produced without involving agro-industry? } & 24\end{array}$

$\begin{array}{ll}\text { Choosing a development model } & 28\end{array}$

Palm oil and health: Fats and fiction $\quad 29$

There is no such thing as the perfect vegetable oil $\quad 29$

$\begin{array}{ll}\text { It's the amount that counts } & 29\end{array}$

How real are these risks? $\quad 30$

$\begin{array}{ll}\text { Label, substitute or boycott? } & 31\end{array}$

$\begin{array}{ll}\text { Towards a sustainable form of production } & 34\end{array}$

$\begin{array}{ll}\text { Must the forest be sacrificed? } & 34\end{array}$

$\begin{array}{ll}\text { Plantations and sustainable development } & 35\end{array}$

$\begin{array}{ll}\text { Ecological intensification } & 38\end{array}$

Roundtable on Sustainable Palm Oil (RSPO) initiative $\quad 42$

Supply of certified sustainable palm oil $\quad 45$

Beyond controversy: What role for research?

Conclusion $\quad 55$

References $\quad 57$

$\begin{array}{lc}\text { Useful Internet sites } & 60\end{array}$ 


\section{Figures and Tables}

\section{Figures}

1. Estimated development of demand for edible vegetable oils in relation to world population growth (after Corley 2009).

2. World prices for crude palm oil (CIF Rotterdam), 1993-2012.

3. Percentage change in the price of crude oil and crude palm oil (CIF Rotterdam), 2003-2012.

4. Oil yield ( $t / h a / y e a r)$ of the main oil producing crops.

5. Part played by main oil producing plants in global production of vegetable oils.

6. Major palm-oil-producing countries. $\quad 9$

7. Main palm-oil-consuming countries. $\quad 9$

8. Global distribution of oil palm cultivation. 11

9. Fatty acid composition of main vegetable oils. 29

10. Evolution of the real uptake of certified palm oil put on the market. 43

11. RSPO certification, book and claim. 46

12. RSPO certification, mass balance. $\quad 47$

13. RSPO certification, segregation. $\quad 48$

14. RSPO certification, identity preserved. $\quad 49$

15. Scientific publications devoted to oil palms and palm oil from 1978 to 2010.51

\section{Tables}

1. Amounts of pesticides used in cultivation of soybean and oil palm (kg/ha/year) 


\section{Acknowledgement}

Rival Alain and Patrice Levang sincerely thank Claire Jourdan-Ruf who lit the first spark and kept the flame alive to reach the publication of the original version of this book. 



\section{Introduction}

Scientists have a part to play in the debate over oil palm cultivation which has captured and polarized public opinion, kindled and undoubtedly shaped by the media.

How can this palm be viewed as a 'miracle plant' by both the agro-food industry in the North and farmers in the tropical zone, but a serious ecological threat by non-governmental organizations (NGOs) campaigning for the environment or rights of local indigenous peoples?

The time has come to move on from this biased and often irrational debate, rooted in schools of thought and issues topical in contemporary society in the North, such as junk food, biodiversity, energy policy and ethical consumption.

Why do we need this book today? What would induce two researchers to abandon their fields of study and their laboratories to enter the perilous arena of public controversy?

Firstly, we think one of the reasons the public has developed such fixed ideas is that there has been a lack of accurate information on the sector and its actors, and a clear headed analysis of what's at stake. We would like to point out that the production and processing of palm oil is part of a complex globalized agroindustrial sector with multiple actors and stakeholders, often at odds with one another.

Secondly, we feel that this sector, which now finds itself in the limelight, symbolizes the evolving North-South relationship in agricultural development. Palm oil is also a showcase for South-South trade and the development of this commerce is mainly driven by newly emerging economies.

As is the case in many industrial sectors - the automobile industry springs to mind, a sensitive sector for France - the countries of the North no longer dominate markets, a situation which will continue for some time into the future. They still play a leading role, not only in innovation (although how long this will last we do not know), but also in challenging the industry on ethical and environmental grounds. In addition, the bulk of agro-food processing involving palm oil takes place in the North, the home of the major agro-food multinationals which are the stated targets of NGOs. The self-appointed role of world policeman taken on by some governments and NGOs in the North is questionable, but it is clear that their dramatic and inevitably oversimplified campaigns have played a direct role in encouraging people to think about sustainability. 
Lastly, since developments such as the controversy in Europe over genetically modified crops, we have become aware of the sensitivity of politicians and decisionmakers to public opinion, which has tended to retreat to entrenched positions.

Some branches of science find themselves denied public funding once they have been publicly categorized as 'sensitive'. Paradoxically, this has the opposite effect to that sought. The debate is generally triggered by a lack of solid scientific evidence, obtained without conflict of interest by independent teams (see the recent Seralini controversy over genetically modified maize). But by depriving a whole field of research of public funding the door is left open to scientific research financed exclusively by private money without any counterweight and therefore open to question.

For the first time ever, it is not a major technological innovation (such as nuclear energy, genetically modified crops or shale gas) that causing controversy but an entire agro-food sector which has come to symbolize the conflict between the conservation of natural spaces and development. Consumers, elected representatives and scientists are all forced to take sides for or against palm oil, with no room for ifs and buts, and very few of them are willing to switch positions.

Distributors, processors, NGOs and journalists have often deliberately overstated the case and resorted to short cuts (oil palms mean deforestation) or superficial information (good-bad fats) to make their point. This type of debate relies on clear-cut and definitive opinions, and researchers naturally tend to query, test out and weigh up each argument. They have nuanced and complex messages to convey which are incompatible with the format imposed by the media. The publication of this book, produced by two people working together, offers a way of clarifying the issues and developments in the sector in a more level-headed manner.

Events which unfolded in France in 2012, such as the Nutella Amendment and the case of AIPH vs. the French retail chain Magasins U highlighted a real gap in knowledge on the part of French politicians and media about the actors and issues involved in this sector. Again, when viewed in the context of changing NorthSouth relations, these news items become particularly revealing and challenging to us, as researchers appointed by public bodies involved in cooperation with the South.

Our respective skills in agro-economics and biology set limits on this book by preventing us from analyzing all the components of the current controversy in detail. However, although neither nutritional impact of palm oil consumption nor environmental impact - the focus of the debate - is part of our research focus we have absorbed a considerable amount from contact with colleagues who are biochemists and nutritionists. Their patient explanations have enabled us to grasp a few simple truths. There is no such thing as the perfect oil with a natural and harmonious balance of all types of essential fatty acids, and palm oil is no different. In terms of fat, the same rule applies as for all the other components of 
The Inter-professional Association of Palm Oil Producers of Côte d'Ivoire (Association interprofessionnelle des producteurs de I'huile de palme - AIPH) against the retail chain Magasins $\mathrm{U}$.

On 4 December 2012 the Paris Commercial Court (Tribunal de Commerce) delivered a judgment in favor of the Inter-professional Association of Palm Oil Producers of Côte d'Ivoire (Association interprofessionnelle des producteurs de I'huile de palme - AIPH) which had sued the chain Magasins $U$ for misleading advertising. A TV advertisement taken out by the chain was alleged to have denounced the adverse effects on health and the environment of the cultivation of oil palms. On the grounds that this represents vilification of palm oil products the court banned any further broadcasting of the film and ordered the $U$ brand to pay a penalty of $€ 3000$ per day should the decision be ignored.

\section{The Nutella tax}

An unusual anti-palm oil campaign was waged by France at the end of 2012, following the proposal by senator Yves Daudigny to impose a surcharge on foods containing this oil. This amendment to the 2013 draft French social security financing law (Projet de Loi de Financement 2013 de la Sécurité Sociale Française - PLFSS), introduced an additional payment of $€ 300$ per tonne on top of the special tax planned for palm, palm kernel and coconut oil destined for human consumption, either as is or after being incorporated into food products. The amendment, which was swiftly nicknamed the 'Nutella tax' was eventually thrown out with the rest of the draft law on social security financing. Its author himself was surprised at the scale of the controversy stirred up by the measured and well-argued reactions on the part of the palm-oil-producing countries of the South. The Malaysian Palm Oil Council (MPOC) immediately queried the dietary and environmental arguments put forward in the draft tax. "Most of the saturated fats consumed in France are of animal origin," it stressed, citing the "101 kilos of meat consumed per person per year, which contain 15 kilos of saturated fat" or the " $30 \%$ fat content of the 24 kilos of cheese" consumed per head per year. Quite apart from the fact that public health issues cannot be solved by banning a single ingredient, the results of taxing fat in other countries have proven disastrous.

our diet, it's the amount that counts. Like butter and pork meats, palm oil mainly contributes saturated fatty acids, the excessive consumption of which is not recommended. However, to impose an outright ban on a single item of our diet is absurd. It is ill-advised to examine the consumption of one form of food and its potential effects on health in isolation from the general context of lifestyle and eating habits. Palm oil which is mainly used in countries in the North as a solid fat at room temperature, will never supplant traditional oils (olive, sunflower and 
groundnut) at the European table. It is invariably consumed in processed products which are rich in lipids: limiting this form of food should enable those who consider it unsafe to significantly cut their palm oil consumption. Unfortunately, current labeling does not yet provide enough information on the nature of the oils present in prepared food.

This book makes no claim to be an encyclopedia. Talented colleagues have risen to this challenge. Its aim is bring together all the information needed to come to a balanced view, with a deliberate (no doubt due to our professional bias) slant towards the South, where all palm oil originates and where most palm oil is consumed. 


\section{Strengths and weaknesses of a unique oil crop}

\section{Past and future expansion}

Progress in the standard of living of the poorest people in the world is accompanied by an increase in their consumption of fat, which will unavoidably pose serious public health problems in the near future.

The rapid urbanization of less developed countries is accompanied by a growing uniformity of life style and therefore diet. Fast food is gradually replacing traditional food and there is little to choose between the diet of the Nigerian 'Homo sapiens urbanicus' and his or her Chinese or Canadian counterpart.

Globally speaking, average consumption per head of fat more than doubled between 1975 and 2010, increasing from $11 \mathrm{~kg}$ in 1976 to $24.7 \mathrm{~kg}$ per year in 2009. However this consumption is unequally distributed over the globe. Whereas people in the North tend towards being overweight or obese and face the cardiovascular risks which come with a diet that is too rich and unbalanced ( $>50 \mathrm{~kg}$ of fat per inhabitant per year in France or the United States) and a sedentary lifestyle, diet in other countries in the South remains chronically low in lipids (10 kg per inhabitant per year in Madagascar).

Public information campaigns on nutrition have begun to bear fruit in certain countries in the North, including France, which has experienced a drop in consumption for several years. This trend does little to compensate for the continued demand of new countries. Corley (2009) estimates that production of fat will double by 2050 (Figure 1), despite uncertainty over the rise in per capita consumption in new countries and the role played by biofuel.

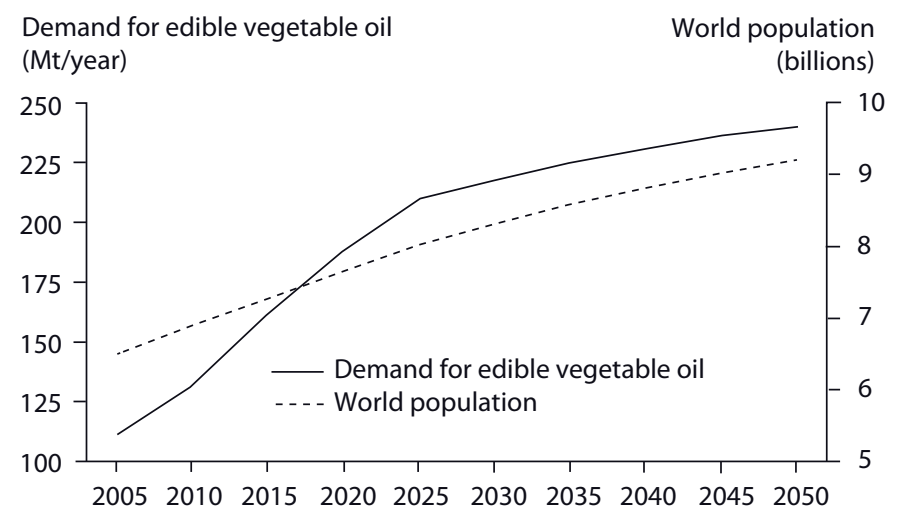

Figure 1. Estimated development of demand for edible vegetable oils in relation to world population growth (after Corley 2009). 
For more than a decade the explosion in demand for fat has had the direct effect of boosting the world price for palm oil (Figure 2), which explains the unprecedented interest of farmers in the South.

In addition, since 2008 there has been a parallel development in the price of vegetable oils, which are potential candidates for biodiesel, and that of crude oil (Figure 3). Clearly, a leap in oil prices will rapidly trigger accelerated usage of palm oil as a direct fuel or biofuel which means there is constant tension in world prices. This potential use as an agrofuel — the case for all vegetable oils, but especially for palm oil because of its low price - provides producers with some insurance against a collapse of prices. Thus, in 2001 the Malaysian government used palm oil as an energy fuel to reduce stocks and maintain prices at a profitable level.

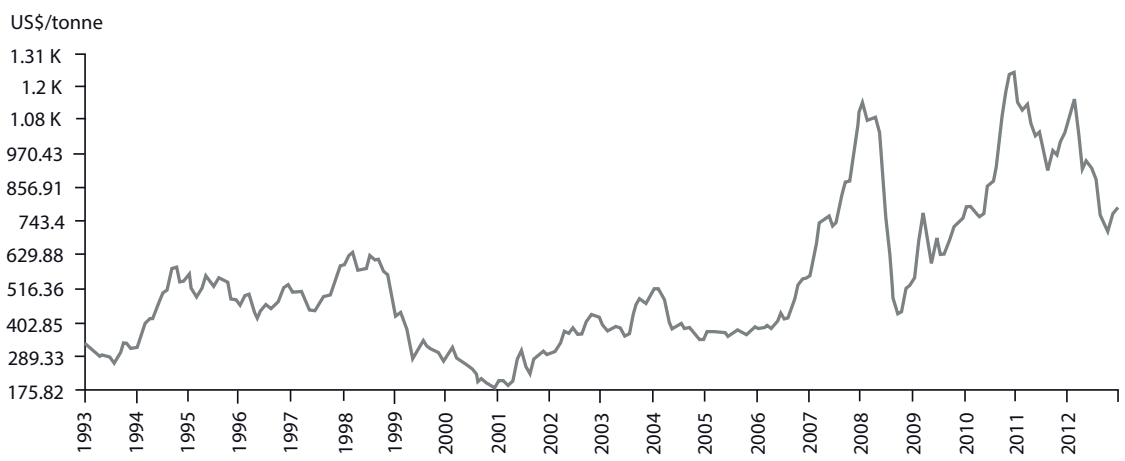

Figure 2. World prices for crude palm oil (CIF Rotterdam), ${ }^{1}$ 1993-2012.

Source: World Bank.

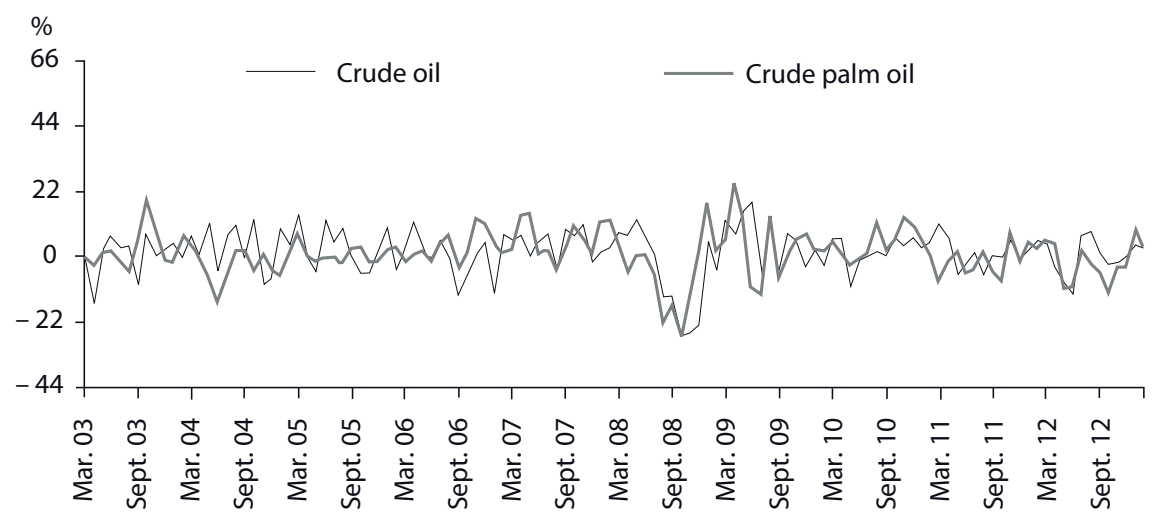

Figure 3. Percentage change in the price of crude oil and crude palm oil (CIF Rotterdam), 2003-2012.

Source: World Bank

1 CIF - Cost Insurance Freight means price includes transport costs from place of production to port of destination. 


\section{A natural oil machine}

The oil palm Elaeis guineensis Jacq. is a monocotyledon which belongs to the Arecaceae family (also known as Palmaceae). This family includes a number of useful species of palm trees used by humans, such as the coconut palm, date palm, rattan palm and heart of palm tree. Although it can grow to over $20 \mathrm{~m}$ high, the palm tree is not a tree but rather a giant grass. Its main enemies are cold (it stops growing at $15^{\circ} \mathrm{C}$ ) and drought (Jacquemard 2011).

Two species of Elaeis are exploited for their oils: E. guineensis, of African origin (Gulf of Guinea) and E. oleifera, of American origin (Amazon Basin). These two species produce oil of very different chemical composition: The oil extracted from the oleifera species is richer in unsaturated fatty acids.

It is possible to hybridize the two species; plant breeders are interested in this prospect because the oleifera palm has morpho-agronomic features which could serve to improve the African species, the main species cultivated today. The Amazon palm has a slower growth rate which allows for a longer period of cultivation because bunches hanging above $15 \mathrm{~m}$ on older palms become difficult to harvest. E. oleifera also demonstrates resistance to diseases such as bud rot, which has had a dramatic impact in Latin America. In this region, planters have no alternative but to create hybrid plantations. Another asset of the hybrid is the quality of its oil, which is lower in saturated fatty acids than the 'African' palm oil.

Within the plant kingdom, the oil palm has a unique feature: Its fruit contains two oils of strikingly different composition. The fruit pulp provides palm oil which is half saturated fatty acids and half unsaturated fatty acids, made up of $44 \%$ palmitic acid (saturated fatty acid), 5\% stearic acid (saturated fatty acid), 39\% oleic acid (monounsaturated) and 10\% linoleic acid (polyunsaturated). Negligible quantities of myristic and lauric acid are also found (remaining 2\%).

\section{Oil palm}

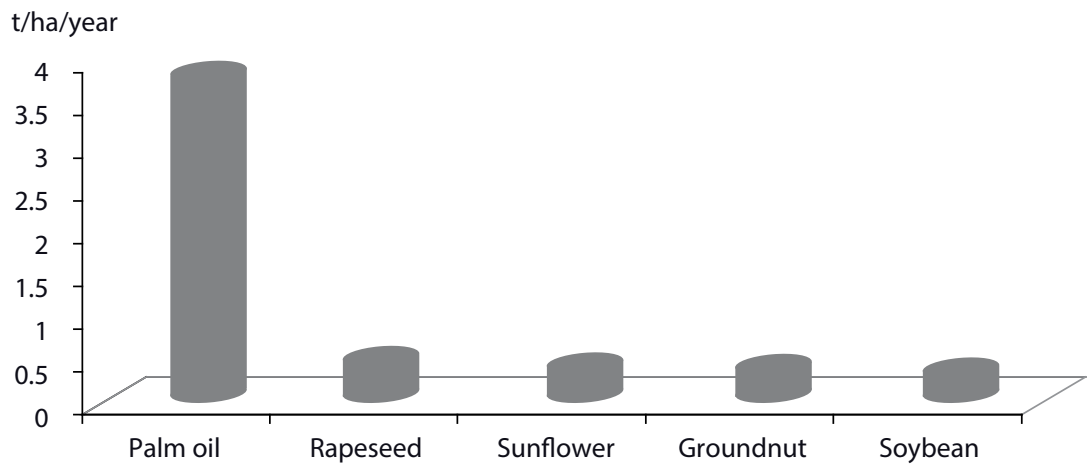

Figure 4. Oil yield ( $\mathrm{t} / \mathrm{ha} / \mathrm{year}$ ) of the main oil producing crops. 
Oil palm almonds provide kernel oil with a chemical composition similar to coconut oil. A significant proportion of kernel oil (82\%) is made up of saturated fatty acids, namely 48\% lauric acid, 16\% myristic acid and 8\% palmitic acid. Nearly $18 \%$ of kernel oil is unsaturated, with $15 \%$ made up of oleic acid (monounsaturated) and 3\% linoleic acid (polyunsaturated). This oil accounts for about $10 \%$ of oil palm yield. It is therefore more than a by-product in terms of the industry's balance sheet. It has the same uses as coconut oil with which it is in direct competition. The numerous uses for kernel oil include cooking oil, when mixed with other vegetable oils (producing such oils as the well known French brand Végétaline), margarine, soap production, cosmetics, and oleochemicals.

The oil palm offers exceptional oil yields of 3.8 tonnes per hectare (t/ha) as a global average, nearly $6 \mathrm{t} / \mathrm{ha}$ in the best plantations in Southeast Asia and more than 10 t/ha in the highest yielding genetic trials currently underway in research institutes. These yields place the oil palm at the head of industrial oil crops (Figure 4). The proportion of palm oil in worldwide production of vegetable oils has continued to grow over recent decades to reach the number one spot, ahead of soybean. Today, it accounts for over a third of the vegetable oil produced worldwide (Figure 5).

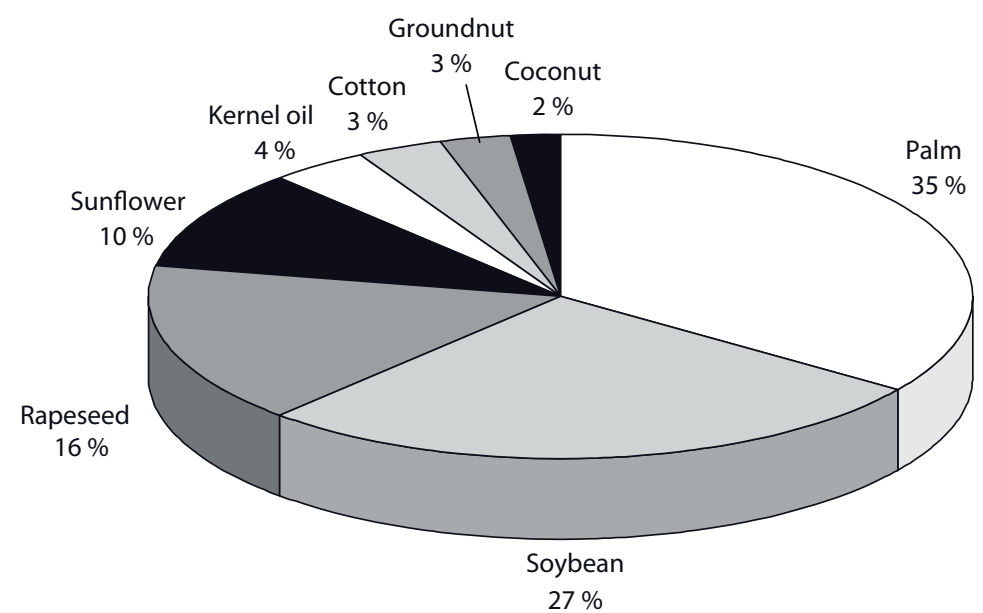

Figure 5. Part played by main oil producing plants in global production of vegetable oils. Source: FAOSTAT.

Although it only occupies $7 \%$ of agricultural land devoted to oil producing plants (Caliman 2011), the oil palm provides 39\% of world production of vegetable oil on a much lower proportion of this land than that devoted to soybean $(61 \%)$, rapeseed (18\%) and sunflower (14\%).

Palm oil also has the lowest production costs of all vegetable oils, $20 \%$ lower than soybean. 


\section{A global sector, sustainably rooted in the South}

Oil palm is cultivated exclusively in humid tropical zones where it represents a major source of cash, both in terms of exports and as a raw material for local industry (fractionation and refining).

Two countries - Indonesia and Malaysia - are responsible for the bulk of world palm oil production, and between them they account for $87 \%$ of supplies (Figure 6).

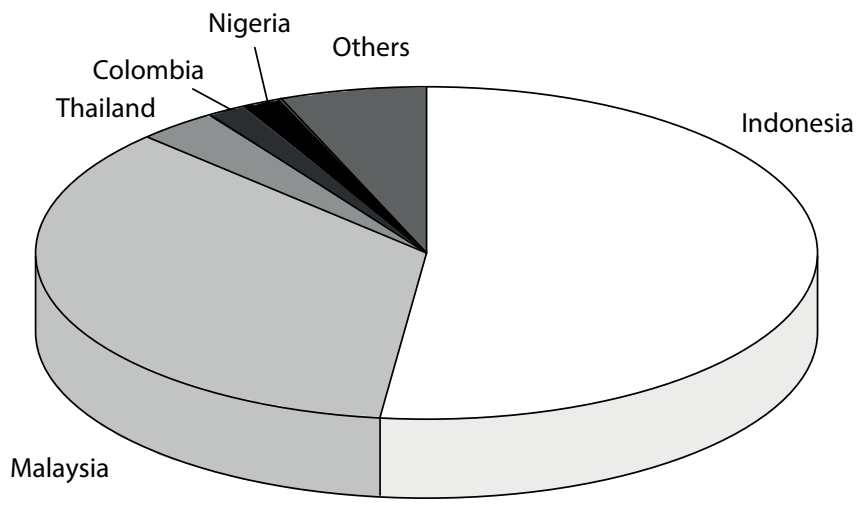

Figure 6. Major palm-oil-producing countries.

Source: USDA-FAS.

Consumption is driven by the countries in the South, and is maintained by demographic growth and the rising standard of living in emerging countries with large populations such as India, Indonesia and China. European consumption accounts for $12 \%$ of the world total and the United States' share is 3\% (Figure 7).

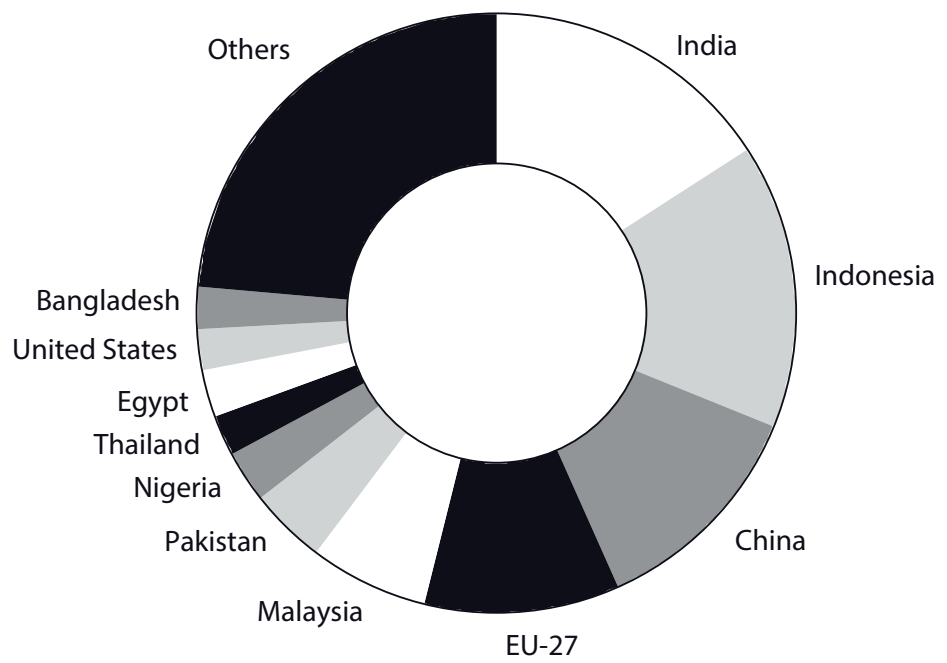

Figure 7. Main palm-oil-consuming countries.

Source: USDA-FAS. 


\section{A versatile crop}

Palm oil can replace most other vegetable oils and has a very wide range of uses in

1. the agri-food industry ( $80 \%$ of palm oil usage): table oil, frying oil, margarines, fat for bakery products, patisserie and all types of food preparation, etc.

2. oleochemicals ( $19 \%$ of usage): cosmetics, soap production, lubricants and greases, candles, pharmaceutical products, leather, surfactants, agrochemicals, paint and lacquer, electronics, etc.

3. biodiesel ( $1 \%$ of usage).

\section{Key physical and chemical properties}

The fatty acid composition of palm oil gives it quite specific practical characteristics which explain why it is so popular with processing companies in the North. In these countries its consistency at room temperature gives it a natural 'melt in the mouth' characteristic which means it can be used as a substitute for butter in many agri-food processing industries (patisserie, confectionery, savoury snacks, ready-cooked dishes and frozen food). These technical and organoleptic properties can be obtained from oils extracted from temperate oil crops (rapeseed, soybean or sunflower) but these oils have to be artificially hydrogenated at the risk of producing trans fatty acids (trans fats), which are legally banned or at least recognized as harmful. Palm oil responds well to the challenge raised at the beginning of the new millennium to find alternative forms of fat with little or no trans fats (FFAS 2012), which explains its success in the food industry.

\section{A flexible species}

Nearly 18 million hectares of land in tropical areas have been planted with oil palms. Although it has been genetically improved since the 1940s, the oil palm remains a very hardy plant and adapts to a very wide range of systems of cultivation. The highly diversified systems of cultivation range from family plots of a few hectares to agro-industrial estates covering several tens of thousands of hectares. The resilience of the oil palm enables it to adapt; oil yields vary according to density of plantation, system of irrigation and fertilization, and any intercropping. The stem (trunk) of the palm tree plays a vital part in this flexibility, enabling it to accumulate significant organic and mineral reserves. Thanks to these reserves, a palm tree can survive an extended dry season, several years without fertilizer and competition from other palm trees or crops planted in proximity, such as maize, cassava and legumes.

Almost half the palm oil produced today comes from small farms. Globally, around 3 million smallholders are involved in the sector. In Indonesia alone it is estimated that 25 million people are now living indirectly off cultivation of the oil palm (WWF 2011). 
Although smallholdings play a key role in global oil production, their importance varies greatly from country to country (more than $90 \%$ in Ghana or Thailand as opposed to $40 \%$ in Indonesia). On some family farms in Africa, particularly in Benin, the oil palm is also planted at very high density (600 to 1.000 palm trees per hectare instead of 140 to 170 ) to produce palm wine or spirits.

In Africa, in addition to the major national or private development projects, there are also small scale farms on which the oil palm is grown not only in rotation with food crops or fallow but also around home plots. These are not exactly plantations (density is low - about 30 to 50 palm trees per hectare) but areas where palm trees are spared during slash-and-burn cultivation. The crop is then simply picked and processed traditionally, by treading on it without even a basic press. The red homemade oil produced is consumed at home as well as sold (Rafflegeau 2008).

\section{Fragile coexistence in the tropics}

The biological requirements of oil palm mean its distribution is limited to the tropics, and it is thus forced to share some of the planet's last biodiversity hotspots, namely the Congo Basin, the Amazon and Borneo (Figure 8). Other major oil crops also have to cohabit fragile environments. The cultivation of soybean $(75 \%$ genetically modified), for example, has to overcome significant environmental constraints, particularly in Brazil where the area under cultivation has increased from 1.7 million to 21.7 million hectares within 40 years.

The relationship between palm plantations and deforestation is neither direct nor automatic. Concessions are granted by public authorities, often at local level, to forestry companies who extract timber. Degraded forests can become fallow

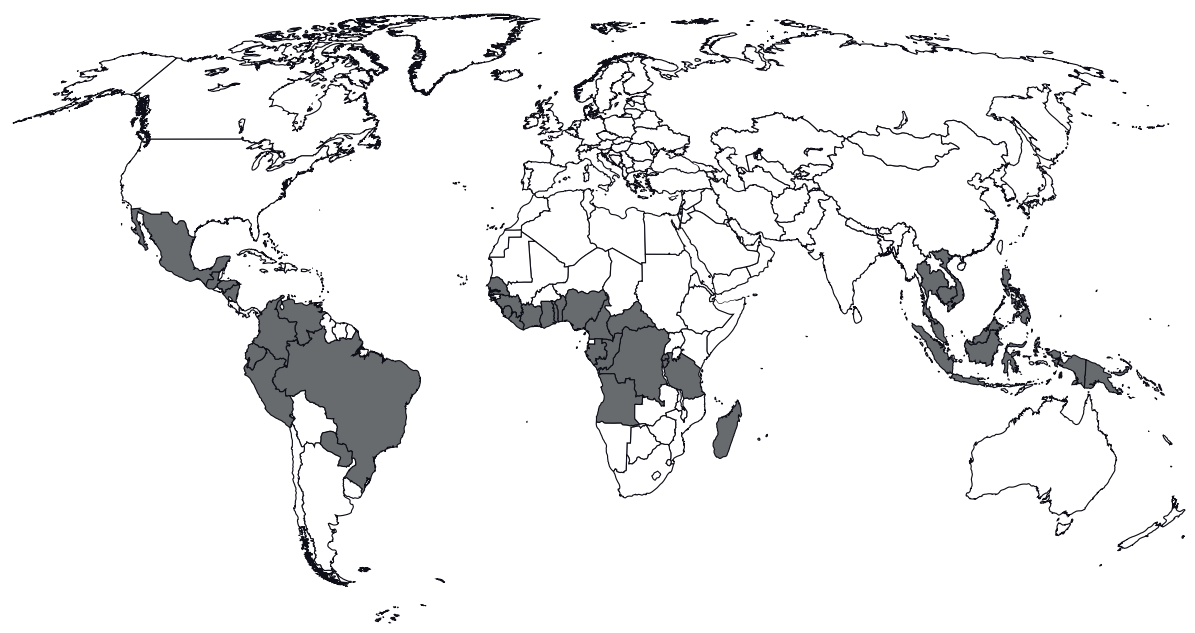

Figure 8. Global distribution of oil palm cultivation. 
land, savannah or farmed land, depending on what people do. Only a portion of deforested land is converted into palm plantations. Out of 21 million hectares of primary forest which disappeared in Indonesia between 1990 and 2005, no more than 3 million have been developed as palm plantations.

However, there are growing signs of a direct link in new frontier areas, such as Borneo, where nearly $30 \%$ of the primary forests felled have been planted with oil palm (Carlson et al. 2012), while on average new plantations are responsible for $10 \%$ of the deforestation that has taken place in Indonesia and Malaysia (FAO 2010). These figures do not take into account the indirect causes of deforestation linked to activities which spring up following the introduction of plantations at the edge of forests; these activities are difficult to estimate but are not negligible.

The major oil palm plantation programs underway in Africa (Liberia, Angola, Gabon, Cameroon) also pose an increasing threat to forests (WWF 2011). As a result of the growing number of international regulations to prevent the conversion of natural forests, shortage of land, monitoring of major land acquisitions and hopes raised by REDD (the reduction of emissions caused by deforestation and degradation) in major producing countries such as Malaysia and Indonesia, the big Asian companies are tempted to diversify their production zones and invest heavily in Africa (Hoyle and Levang 2012).

Indonesia anticipates doubling its production between now and 2020, while West Africa and the Congo basin offer a new frontier (650,000 hectares in the planning stage in Liberia alone). 


\section{Who really benefits from oil palm cultivation?}

\section{The oil palm, miracle or curse?}

Clearly, the oil palm deserves neither this exaggerated honor nor this indignity. E. guineensis is just one of many cultivated plant species with both positive and negative features, depending on how we choose to use it, although it of course has no say in the matter. According to its detractors, some of the plant's features mean that it is primarily destined for agro-industry. But is there such a thing as an industrial plant? In the past, cotton and sugar cane were referred to as 'slave crops'. Today such an allegation would be laughable, so clear is it that the way a crop is cultivated does not depend on the plant as such but on the global organization of society and its level of technical development. Whereas in the past recourse to mass, cheap labor was the rule, mechanization and motorized transport have provided new answers. What does this mean for the oil palm?

\section{Palm oil as a forest product}

Before becoming the prima donna of agro-industry in Southeast Asia and the bête noire of environmental NGOs, palm oil began its career as a simple forest product ${ }^{2}$ in Africa. E. guineensis originated in the humid tropical forests bordering the Gulf of Guinea in the both West and Central Africa. The species is endemic to forests in the tropical zone countries of Sierra Leone, Liberia, Côte d'Ivoire, Ghana, Togo, Benin, Nigeria, Cameroon and to the equatorial zones of Gabon, Republic of Congo (Congo-Brazzaville), Democratic Republic of Congo (Congo-Kinshasa) and Angola (Bakoume 2006). The natural palm groves in countries bordering the Gulf of Guinea are in fact semi-domesticated: people just encourage the plant to develop. Because the reproductive capacity of the palm is high (several bunches each with several thousand fruit per year!), it proliferates naturally and does not need to be planted. The seeds are dispersed by animals and people at harvest time. The palm tree is a pioneer species which develops particularly well in areas cleared as a result of slash-and-burn cultivation. Fire increases the germination rates of the seeds and the trunk can withstand everyday fires (Swaine 1992; Maley 2003). As is the case for many forest products, anyone who discovers a palm tree in the forest becomes its legitimate owner. He or she applies their mark, pruning the lower

2 Or Non-Timber Forest Product (NTFP) to use the expression currently employed in ecological circles. A seminal article by Peters et al. (1989) which appeared in Nature concluded that the reasonable exploitation of forest products other than wood by indigenous inhabitants of the Amazon was more economically effective over time than conventional forest farming. This article triggered an unprecedented boom in interest in NTFPs, regularly presented as a viable alternative to forest exploitation or forest conversion. In ecological circles, oil palm is often described as the archetypal industrial plant responsible for the disappearance of the forests. However, in the original habitat of E. guineensis, palm oil is a perfect fit for the definition of a NTFP. 
leaves from the stem and is the only person entitled to collect the bunches or fell the palm tree to produce palm wine. However, when a palm tree starts growing spontaneously on farmed or previously farmed land, the palm tree becomes the legal property of the owner of this piece of land (Bakoume 2006). When a natural palm grove or stretch of land with palm trees is farmed, every precaution is taken to prevent the palm trees from being damaged by the process of slash and burn. Thus, the spread of palm plantations owes much to the spread of farming. Bit by bit, forest products become integral parts of a complex system of agro-forestry. Depending on the means available and the approach of the farmer, palm trees may be treated as a species to be harvested in the forest, a species growing wild but protected within the cleared land resulting from slash and burn, a species planted alongside other crops as part of complex agricultural systems or, finally, a species grown in a monoculture. Many different types of cultivation continue to exist today in the areas where oil palms originated (Rafflegeau 2008). In other words, the widespread reputation of the oil palm as the archetypical monoculture needs to be revised.

The oil palm is also a multipurpose plant. The flavorsome oil extracted from its fruit, red in color because of its high carotene content, is an essential ingredient in a number of traditional dishes made in West Africa and northeast Brazil. The oils produced in some regions of West Africa are highly prized by connoisseurs which boosts their prices. But this red oil is not the only product of the oil palm. It also yields palm kernel oil extracted from the endocarp, palm wine, heart of palm and a range of materials for building or traditional crafts: leaves as thatching for roofs, plant stems for fencing and to strengthen earthen building materials, baskets, nets, ropes, brooms, etc. In Cameroon, palm kernels are grilled to produce a black oil called magnanga, famous for its numerous medicinal uses (Bakoume 2006). Palm kernels are also used to make soap, unguents and massage creams. The use of nuts to make oil goes back to the beginning of time. The oldest evidence of the use and sale of palm oil dates back to $3000 \mathrm{BC}$, with the discovery of several kilos of oil in an Egyptian tomb in Abydos. Analysis of the oil has proved beyond doubt its place of origin and there is every likelihood that Arab traders were already selling palm oil between the Gulf of Guinea and Egypt, 5000 years before the boom in oil palms (Friedel 1897).

\section{Palm oil exports take off}

Between the 14th and 17th centuries, merchant ships on their way back from Africa occasionally tried to sell palm oil in Europe but did not manage to compete with olive oil or butter. For a long time therefore culinary use of palm oil was restricted to Africa. International trade in palm oil only really began at the very beginning of the 19th century, and that of palm kernel oil slightly later, in 1832 . With the end of slavery, slave ships were recycled to transport palm oil. The Industrial Revolution in Europe together with progress in hygiene opened up new markets for palm oil products. Palm oil became the main industrial oil used in tinplating, while palm kernel oil found a niche in soap manufacture. In the 1870 s, 
Nigeria was exporting 25,000-30,000 tonnes per year. By 1911, exports from all the territories under British rule totalled 87,000 tonnes. Exports of palm kernel oil from this area reached 157,000 tonnes in 1911, of which three quarters came from Nigeria (Hartley 1988; Kiple and Ornelas 2000).

With the explosion in demand, palm oil rose from being a traditionally gathered subsistence product to an export product. The effects were swift. In the Asante Confederation (in the west of today's Ghana), the state slaves were put to work creating vast palm plantations and in 1856 King Ghezo passed a law in the neighboring kingdom of Dahomey (today's Benin) prohibiting his subjects from cutting down palm trees. But the traditional palm groves could not cope with demand and the peasants, adapted to subsistence farming, were not really prepared to produce for the international market. When they were, they often preferred to devote themselves to cocoa, as in Ghana and Nigeria after 1880 (Fournier et al. 2001). Direct colonial intervention became vital.

\section{The arrival of colonial plantations}

The first experimental oil palm plantations were introduced in 1870 in Gabon by Catholic missionaries. But attempts to establish colonial plantations generally failed. This was because most planters found themselves in serious debt due to the heavy investment required to set up in Africa and were therefore sensitive to fluctuations in price, not to mention the difficulties of finding labor and the lack of technical understanding of tropical crops.

The Germans were the first to make some headway by applying modern methods of palm oil cultivation in their plantations in Cameroon. Cameroon's first agroindustry was set up in Edea in 1907 but progress was cut short by the First World War and the transfer of the German colonial administrative role to Britain and France in 1919.

When in 1907 William Lever tried to obtain land in West Africa to supply his soap factories in England, the British colonial administration refused to support him arguing that such plantations would not be accepted by local people in places which were already densely populated, such as Nigeria, and as a result would cause problems later on. Lever therefore decided to try his luck in the Belgian Congo where the colonial power was more open to investors. The concession that Lever obtained in the Belgian Congo in 1911 marks the beginning of a real revolution in the palm oil sector (Fieldhouse 1978). This revolution involved both production, with the introduction of new hybrid seeds, and processing, with the development of new presses and forms of treatment.

Back in 1902, German botanists in Cameroon had identified a 'lisombe' palm tree ,later better known by the designation 'tenera'. This palm tree produced fruit with small kernels that had a high oil content but it was rare in the wild and reproduced poorly (Hartley 1988). The Belgians developed an interest in this new type of 
palm and created the first experimental tenera plantation at the Yangambi research station in the Congo in 1922. In 1941, M. Beirnaert discovered that tenera was in fact a hybrid of dura (large kernels) and pisifera (no kernels). This discovery was to open the way to the production of high-yielding hybrid seeds (Hartley 1988). It is striking that neither the Congo nor Africa more generally went on to make the most of this discovery. New actors had appeared on the scene.

The first oil palms to arrive in Southeast Asia were four plants from West Africa which had were introduced into the Bogor Botanical Gardens in 1848 (Hartley 1988). It was not until 1905 that Adrian Hallet noticed that the dura palms which descended from these first plants and had been introduced in Sumatra, grew better and produced fruit with smaller kernels and higher oil content than the dura of West Africa (Leplae 1939). Their superiority was due to the more favorable ecological conditions in Sumatra (fertile soil, regular rainfall and high levels of sunshine) not to mention the absence of the pests and diseases encountered in the zone of origin. The restricted origin of the genitors (four mother plants) ensured the plant material had a high degree of homogeneity, although this very narrow genetic base was to become a headache for geneticists!

The relatively high yields of plantations combined with the reduced risks spurred rapid development of the sector. In 1910, Hallet's trials were taken over by his friend Henri Fauconnier in Malaysia. The surface area devoted to plantations grew steadily in the two countries bordering the Malacca straits. The success of the sector was not unrelated to the difficulties which rubber cultivation was experiencing in both countries at the time of the 1929 crash. Oil palm cultivation was then seen as a form of diversification for colonial plantations. On the eve of the Second World War, Sumatra had 90,000 hectares of oil palms while Malaysia had 30,000 hectares.

Despite the rapid success of colonial plantations in Southeast Asia, West Africa with its 2.4 million hectares of natural palm groves, 72,000 hectares of colonial plantations and 97,000 village plantations in Nigeria, remained the world's number one producer of palm oil at the end of the 1930 s.

\section{Stagnation in Africa, boom in Southeast Asia}

In the-post war period, with the major colonial powers bled dry by the conflict, investment in Africa was sluggish. The 1960s saw decolonization and independence for British and French colonies. Most of the countries bordering the Gulf of Guinea opted to diversify their agriculture with projects to develop palm trees, rubber and, above all, smallholders' crops such as cocoa and coffee. In Indonesia, the struggle for independence, followed by the nationalization of colonial plantations and then the constant strikes orchestrated by the Indonesian Communist Party halted development of the industry until 1970. 
Malaysia emerged best from the situation. Already in the 1950s, the Malaysian government and the private sector were launching programs to select varieties and produce hybrid tenera seeds. The new palms were not only more productive but they yielded a type of fruit which was perfectly adapted to the new screw presses which had been developed in the Belgian Congo and were in use in all Malaysian factories after the mid-1960s. At the same time, and particularly after the 1960s, the Malaysian government took the step of converting its old rubber plantations into oil palm plantations through FELDA projects designed to develop village plantations. In 1966, Southeast Asia overtook Africa in terms of palm oil production, a gap which was to continue to grow.

\section{FELDA, Malaysian Federal Land Development Authority}

FELDA was founded in 1956 mainly to launch the rural development of a large number of Malaysian smallholders, left out of the process of economic development. Through agricultural resettlement projects, with tight technical management, FELDA planned to create a class of Malay smallholders who would have an up-to-date and efficient approach. The initiative covered both rubber and oil palm plantations. In 1961, FELDA developed its first 375 hectare palm plantation, swiftly followed by many more. In 2000, FELDA was in charge of more than 685,000 hectares of oil palm.

\section{A development steered by the processing industry}

The beginning of the 20th century saw the development of hydrogenation of animal oils, a process by which liquid oils become more malleable or solid at room temperature, features sought by the food industry. Because palm oil is solid at room temperature in temperate countries and does not require hydrogenation, fat of plant origin gradually replaced butter, lard and suet in the production of cakes, patisserie and biscuits, and as a frying oil. The introduction of vegetable oils from the major colonial plantations (coconut and groundnut) which was more stable, better refined and less acidic meant that palm oil steadily gained market share in both the food and cosmetic industries.

The boom in prepared food, such as savory crackers and crisps, from the $1950 \mathrm{~s}$ onward offered a new niche for palm oil because of its enhanced resistance to oxidation and its capacity of being fried at high temperatures. In anticipation of a marked increase in production following large-scale replanting in the 1960s, Malaysian planters, in conjunction with the government, set about organizing the promotion of their products both in West and in South Asia. Refineries developed production lines adapted either to the demand for high quality oil by Western agro-industries or to the production of cheaper fat intended to replace clarified butter (ghee), which had hitherto dominated the Indian and Pakistani markets. 
Growing demand led to the development of larger and larger processing units which were entirely mechanized, with motorized transport, and capable of handling large quantities of fruit, using standardized and monitored procedures, and producing higher quality oil. The Malaysian government encouraged the development of a modern refinery industry by offering first subsidies and then tax exemptions. The level of tax exemption on the export of crude palm oil (CPO) was in proportion to the quality of the refined oil. This facilitated its penetration of the European market but its overriding success was in the new Asian markets. In 1983, Malaysia alone was producing more than 3 million tonnes of CPO, while African production as a whole had plateaued at 1.3 million tonnes. But a new actor was about to make an appearance!

\section{Enter Indonesia}

In 1983, thanks to the implementation of the Green Revolution, Indonesia was on the point of returning to self-sufficiency in rice, one of General Suharto's priorities. The next objective was to be development of the industrial plantations of rubber, oil palm and sugar cane.

In 1983, development of the oil palm sector was first entrusted to the Ministry for Transmigration, with the support of state plantations (PTP-PNP) which had evolved from the former colonial plantations nationalized after independence. The development model they followed, called PIR-Trans (Perkebunan Inti Rakyat Transmigrasi), had been adapted from the NES (Nucleus Estate and Smallholders) model which had proved itself in Malaysia (Levang 1997). In exchange for free access to substantial land reserves $(5,000$ to 10,000 hectares of State forest) the plantation company undertook to develop around the nucleus (inti) an equivalent area of plantation designated for smallholders (called 'plasma' by analogy with cell structure). These smallholders were migrants from the most densely populated areas of the archipelago (Java, Bali and Lombok) who were resettled in Sumatra, Kalimantan or Sulawesi. The Ministry for Transmigration was responsible for recruiting, transporting and settling transmigrants ${ }^{3}$ in the villages set up around the plantations.

The companies were responsible for physically developing the site by, for example, clearing, establishing plantations, training migrants and constructing the oil mill. The State guaranteed the bank loans granted to the companies. The development cost of the 'plasma' (non-industrial part) was billed to the migrants and deducted from the purchase price of the oil palm fruit. This scheme was particularly advantageous for the companies which got free access to the land and benefited from a more or less captive labor force, all under the patronage of the government. The operation was also worthwhile for the Ministry for Transmigration because a substantial share of costs was met by the company and the transmigrants and

3 Neither emigrant nor immigrant, transmigrants are migrants who move within a country. 
technical training was carried out by professionals. Private companies which wished to develop plantations could also do so but they had to buy the land from the State and recruit paid workers. The land awarded to companies was in principle State-owned land but sometimes local people were expropriated without any real compensation, particularly during the Suharto era (1967-1998).

After the 1980s, a new model called KKPA (Koperasi Kredit Primer Anggota, literally Members' Primary Credit Cooperative) was developed. With a structure fairly similar to PIR-Trans, KKPA aims to associate a private or public company with transmigrant or indigenous smallholders. They are brought together in a cooperative within the framework of an agreement with a company and a bank. The planters entrust their land to the company which plants, manages and harvests palm fruits. The planters meet all development costs through a levy on the sales price of the fruit. The District government participates in the implementation of projects by facilitating negotiations between companies and villagers and by ensuring titles to the property are handed over. These titles are kept by the bank as collateral until the debt is paid off. The company is responsible for recovering the sums of money lent to planters who commit themselves to delivering their entire yield to the company oil mill. Under this system, the company no longer obtains the land free from the State but directly from local communities. Many variations exist in terms of the surface area a villager has to hand over to the company in order to obtain a small oil palm plantation. These proportions serve to define the variations, for example $80 / 20$ or $70 / 30$ or even $60 / 40$. The most usual pattern, $70 / 30$ means a villager has to hand over 10 hectares to the company to be allocated in return 3 hectares of plantation ready to bear fruit, but not necessarily on his or her former land. Sometimes a small financial compensation is paid to ease the exchange, but whatever the scenario the smallholders have to repay the cost of developing their plantation. About 30\% is deducted from the sale price of bunches until the debt is completely paid off.

The terms of the deal may appear unequal but it must be remembered that in areas which are still largely forested, land value is low and without the involvement of companies, smallholders have no access to selected seed, agricultural inputs, loans or technical support. The arrangement is therefore considered acceptable, even at the ratio of $80 / 20$, when companies first turn up in a forest village. But the situation swiftly changes and a few years later companies find it increasingly difficult to negotiate contracts. Planters who wish to do so can entrust their plantation to the cooperative which will take care of all the work involved in upkeep and harvesting. The owners of the land receive a net monthly income without having to contribute in any way.

Since 2000, primary credit cooperative style projects (KKPA) have become rarer and companies are finding it increasingly difficult to gain access to land. The smallholders make use of the existing infrastructure to develop their own plantations and choose to sell to the highest bidder. More often than not new plantations are developed by planters who are already prosperous and offer their 
plantation as a guarantee to obtain the credit necessary to extend it, or town dwellers who would like to diversify their source of income by investing in proven products. While the isolated peasant was happy to exchange 10 hectares of land for 2 hectares of plantation, pressure on land (and consequently the price of it) is such that indigenous people now feel they have been swindled.

Indonesia has become the world's top producer of palm oil in a record space of time. By 2011, the country was producing 25.4 million tonnes of palm oil from an area of 8 million hectares. Roughly $40 \%$ of the total area taken up by plantations was in the hands of smallholders tied by contracts to agribusinesses or independent companies.

\section{The oil palm, a good or bad business for local people?}

The success of the oil palm was swift to breed criticism. At the end of the 1990s the oil palm became the bete noire of NGOs concerned with protecting the environment and the rights of indigenous people. Oil palm was accused of every kind of evil, responsible for both degradation of the environment (such as conversion of primary forests, loss of biodiversity, disappearance of wild fauna and pollution), increasing poverty of indigenous people (such as land grabbing, dispossession, disappearance of forest resources, forced modification of lifestyle and excessive debt) and a range of attacks on human rights (enforced displacement of people, intimidation, violence, starvation salaries, unhealthy working conditions and, in the worst case scenario, rape and murder). In spite of the negative picture painted by some NGOs, oil palm continued to spread through the archipelago, often at the express request of the local people. By way of illustration, on each of our visits to a village still 'spared' by oil palms, the villagers enjoined us to contact a palm oil company on their behalf and encourage it to approach them. In villages which have now been 'subject' to oil palm for several years the visitor is struck by the high proportion of permanent houses with tinted windows and concrete colonnades topped by Corinthian capitals and by the number of motorbikes and cars and the numerous mobile phone shops. The change in lifestyle is obvious, but where are the signs of the increasing poverty we have heard so much about? In the meantime, NGOs continued to denounce the numerous conflicts pitting local communities against the palm oil companies, conflicts which were supposed to illustrate the rejection of oil palm by local people.

What is really happening? Is oil palm a driver of development, as the companies claim or the harbinger of increasing poverty, as NGOs maintain?

The picture is more complex; oil palm is neither one thing nor the other but both at the same time. The verdict differs depending on the site chosen, period involved and individuals asked. And even then the jury may still be unable to agree. 


\section{The oil palm as a real driver of development}

At the beginning, oil palm is always viewed by local people as the best way out of underdevelopment and of gaining a toehold in the modern way of life. In the isolated forest areas of Sumatra or Kalimantan, local people dream first and foremost about tarmac roads, electricity, water supply, mobile phone networks, schools and dispensaries, even international airports. Living in harmony with nature by hunting and gathering forest products, far removed from the stress of the modern commercial world is the dream of the affluent urban westerner and not that of the 'noble savage'. When the companies' door-to-door salesmen turn up, offering a high and regular source of income, salaried jobs and modern infrastructure they are not forcing anyone's hand but are meeting a real demand. The terms of exchange may sometimes be unequal but it should not be forgotten that land is abundant and cheap on the forest margins of the archipelago. Loans, work, selected seed and agricultural inputs are, however, rare and expensive. And if the forest people have any lingering doubts, the local government representatives and their village leaders can easily dispel them. Planting palm trees is a national project. If Malaysians are rich, it is thanks to the palm. The comparison hits home. Malaysia is the neighbor which succeeded, the neighbor they would like to emulate. The few doubters are accused of being behind the times, of holding up progress or being antisocial. If enough of them resist and if they know how to stay grouped, their lands will be excluded from the deal and treated as enclaves. Part of the land granted to the company will be handed over to transmigrants from Java or Bali and these settlers will provide the labor which is lacking locally.

Once the deal has been struck the dream may take some time to come true. The work takes longer than expected and between clearing and the official handing over of plantations years go by and the cash made from giving up the land is just a distant memory. In the worst case scenario, the vision of a new life of luxury just around the corner leads peasants to neglect preparation of their food crop plots. The early stage of production of the plantations is disappointing, yields are low and do not meet the family's needs. Often finding themselves in debt, these families have no choice but to sell off their plots of palms at a low price to their better-off neighbors or to migrants. A few years later, when the palm trees enter into full production, the sellers have nothing left but the clothes they stand in. Their land capital has disappeared and their only option is to seek jobs as laborers at the company in order to survive.

For those who know how to wait or have the means to do so the situation is different. Seven years after being planted, the oil palm enters the mature phase of production. Despite the $30 \%$ levy to reimburse the loan, the owners benefit from a steady source of income, and have the security to allow themselves to contemplate the future with more serenity, put money aside to educate their children or even expand their land holding. When the start of the mature phase of the plantation co-incides with high palm oil prices, as in 2008, some planters choose to accelerate the reimbursement of their debt, paying it off in as little as 6-8 years (Feintrenie et al. 2010) 


\section{Good for some, bad for others}

The contrast between the two groups is striking. The arrival of oil palm triggered marked social and economic differentiation within the indigenous community. Before palm made its appearance there was already a difference between rich and poor families, but it was much less obvious. All families had land and a minimal income from slash-and-burn cultivation, the exploitation of rubber agro-forests or collection of forest products. Well-off families also had income from trade, transport or government jobs. With oil palm the better-off got richer, more often than not at the expense of their poorer neighbors. The latter often lost everything, not only their land but also access to the nearest forest resources, following conversion of the forest into plantations. Their resentment is directed first at the company, which they feel has duped them and which they identify with oil palm, but also at those near to them who have succeeded, and even more strongly at the transmigrants who have usually done better out of the business. This group had no land reserves at the outset so were not tempted to sell their plantations. As they come from areas where the population is dense, land scarce and labor cheap, transmigrants are used to working hard and have only oil palm to help them escape poverty. The contrast is striking in areas of transmigration which have been turned over to oil palm. In barely 10 years, poor transmigrants have become rich planters.

It is plain to see that the introduction of palm has had both positive and negative consequences, depending on the group considered. In general, those who opted for oil palm have benefited. Those who sold their land or plantation before it entered into full production feel they have been short-changed. Not only did they sell their land at a low price when the company first approached them, but 10 years later this same piece of land has acquired considerable value, only adding to their sense of frustration. This bitterness can be passed on from one generation to another, with the children and grandchildren of the seller feeling that their parents or grandparents were duped or forced to sell up. Is oil palm to blame? Yes and no. Oil palm is only ever an opportunity for development offered to the local population as a whole and something only a proportion of them will be able to take advantage of. The same would have applied to any other cash crop or new opportunity. By way of example, the introduction of aquaculture in the form of floating cages or pools in Sumatra and Kalimantan had a similar impact. In spite of the loans and supervision offered to the village as a whole, after just one or two breeding cycles many heads of family abandoned aquaculture to the benefit of a handful of well-off families who bought up their cages and pools by the dozen, for a song. The development of open-cast coal mines in Kalimantan followed the same pattern. Landowners accepted money from the companies, spent without thinking, forgot to invest in alternative activities and soon found themselves without resources. 


\section{Conflicts provoked by the oil palm}

Very rarely do these cases of improper sales of land by some members of a community lead to real conflicts. Furthermore, none of the numerous conflicts between local communities and companies, flagged by NGOs, involves rejection of oil palm as a crop. Out of the 119 conflicts identified in West Kalimantan by NGOs between 1999 and 2009, we have studied, 49\% involved land disputes with the company, $20 \%$ straightforward rejection of the company, $17 \%$ problems relating to sharing out expenses and income, $8 \%$ broken promises and the rest revolved around pollution, conflict within the community, theft of oil palm bunches or improper action by the company. Land disputes are numerous and diverse, usually involving wrongful clearing of land by the company without the agreement of those involved, and clearing of zones considered sacred or old burial grounds. All sorts of things can happen, such as accidental clearance stemming from a mapping error, deliberate clearance without authorization (forcing the owner's hand), agreement by some beneficiaries but recrimination by other members of the family, and claims for compensation from the company over cemeteries (real or alleged). Although companies are not always beyond criticism, local communities also know how to find ways, which may not always be above board, to make companies pay.

In $20 \%$ of cases, local communities rejected the company's offer, which the NGOs tend to read as a rejection of oil palm. In point of fact, the rejections were motivated more by scarcity of available land or because the community did not view the offer as attractive enough. The company would then sometimes try to overcome this rejection with the official or tacit support of local authorities, and sometimes, influential community members. During the Suharto period, not only did improper clearing by companies go unpunished but local communities hesitated to protest. Since the reformasi, local people defend their rights with the active support of numerous NGOs. Disputes are often the subject of complaints filed with the courts. Because the legal process takes so long unhappy communities sometimes organize violent demonstrations which inevitably end in attacks on public property with cars and offices set on fire. At this point the justice system is swifter to intervene and the troublemakers are liable to find themselves in prison. It is then quite easy for NGOs and the press to denounce a two-speed system of justice - slow to deal with rich companies and fast to tackle poor peasants. The judges tend to argue that trying to prove that a clearing has been made illegally is much trickier than judging troublemakers who appear in court almost immediately.

Another source of conflict is deciding how plantation expenses and income should be shared between company and community. Methods of calculation are often opaque and occasionally certain expenses are improperly charged to the local community which, to complicate matters, has no means of oversight. But very frequently, these expenses are justified and covered in the contracts that smallholders may not always have read before signing. People are more likely to 
rely on the verbal promises made by the local authorities which intercede between them and the company. Should a dispute arise later on, the words of a public servant who has since moved on are worth little in comparison with a contract written and signed by both parties.

The other conflicts that arise usually come under penal law such as fraud, theft and embezzlement, all of which are commonplace in financial transactions in Indonesia and elsewhere, and which it would be unfair to attribute to oil palm. The same goes for human rights violations that some NGOs have blamed on oil palm. Again, we must be clear about the target. Oil palm is not in any way responsible for the actions of some companies or their henchmen. What cannot be condoned is the seizing of local people's land by a more powerful third party. The use to which the land is ultimately put (cultivation of sugar cane, Acacia mangium, rubber plants or oil palms, or mined for coal) is not reprehensible in itself. What is reprehensible is the act of stealing, not the use of the stolen asset. In the same vein, some NGOs, usually quite rightly, condemn such things as poor working conditions in the oil palm companies and the ill treatment meted out to individuals by security staff. Here again, the oil palm itself is not responsible for the management methods used by company staff. Palm oil companies are unfortunately no different to those in other sectors. Generally speaking, management and skilled personnel employed by companies enjoy quite favorable working conditions, such as competitive salaries, good schools and grants for their children, and fully equipped dispensaries with doctors and nurses in place. Competition between companies is tough and skilled personnel are too scarce to be ill-treated. However, any task requiring large numbers of unskilled laborers with few or no qualifications is contracted out to agencies which cannot afford to show their labor force the same generosity. The companies' contract specifications put pressure on subcontractors which, in return, exploit their labor force. As long as labor is scarce, working conditions remain acceptable. But the moment crowds of laborers show up seeking jobs, working conditions deteriorate, daily wages are replaced by piece work, targets rise and payment rates lag behind. But is this peculiar to oil palm? Surely not.

Modern agro-industries are directly descended from the former colonial plantations. They share the same organization of space and staff and face the same problems and solutions (Bissonnette 2012).

\section{Can palm oil be produced without involving agro-industry?}

Contrary to what we are frequently told, palm oil production not always need to involve the agro-industry. The forest populations of the Gulf of Guinea were producing red oil for local needs several millennia before the Industrial Revolution. Even today in the original home of E. guineensis, a large proportion of production originates in village plantations - the established term for plantations in the hands of independent smallholders. The surface area of these plantations varies, from around a hectare for the smallest to several hundreds of hectares in 
the case of plantations belonging to the urbanized elites. The oil is usually pressed and processed by traditional methods and sold locally. In Cameroon, at times of low production (June to December), almost all bunches grown by small-scale planters are processed directly by the producer or in traditional mills set up near the plantations. During peak production (January to May), the traditional mills do not have sufficient capacity and most of the yield is delivered to industrial oil mills. The Cameroon Ministry for Agriculture, the companies and 'experts' regularly condemn what they call a shocking waste. And it is true that yields from industrial mills are on average 50\% higher than those from traditional presses, which leads to a significant waste of oil, quite apart from the lack of quality control, pollution problems and poor working conditions for the labor force. But in spite of the lower yield, the economic return is worthwhile for the smallholder. During the low season, the price of traditional red oil increases sharply on the local market, whereas the sale price of commercial oil is set by decree and remains stable throughout the year. The price difference more than compensates for loss of yield in processing fruits and the additional value goes directly to producer and processor. In addition, the activity employs many local people and has a multiplier effect which results in intense economic activity in production areas.

In Indonesia and Malaysia, smallholders own $40 \%$ or more of the surface area of plantations, a share which is continually growing. An increasing number of smallholders are becoming independent of the big groups and are happy to just deliver their fruit bunches to the company oil mills. The first smallholders were forced to sell their yield to the region's single oil mill but the emergence of numerous competing firms has changed the situation. Competition - between mills, transporters and plantation developers - works to the benefit, not only of smallholders, but of small and medium investors. More and more town dwellers, business people and civil servants are seeking to buy land to develop plantations. Demand also extends to already established plantations, causing land prices to rocket. Those owners who have been able to retain their land now command a real fortune. Those who sold their land and plantations at a low price at the outset are no longer able to access land and find themselves increasingly marginalized.

In Indonesia, the Oil Palm Smallholder Development and Revitalization Program launched in 2007 has now reached $c a 220,000$ hectares. It is funded by the Loan Program for Plantation Revitalization and through a partnership involving 102 companies and investment totalling Rp 8.6 trillion (543 M€).

As the examples of Malaysia and Indonesia show, the help of agro-industries is initially indispensable to carrying out clearance and planting, gaining access to selected planting material and improving access to agricultural inputs, organizing the transportation of bunches to the oil mill, and obtaining titles to property and guaranteeing bank loans. Furthermore, since the oil palm was a new crop for smallholders in Southeast Asia, the transfer of knowledge and learning of techniques required the assistance of public or private companies. Later on, as can be observed in the oldest production areas, there is no real need to involve 
agro-industry. Once the industry is established, family farming can take over from agro-industry and deliver primary production. However, agro-industry-continues to have a dominant role to play at the stage of processing and marketing of palm oil. Industrial scale units are essential when it comes to producing large amounts of standardized quality oil for export.

In Africa, in the countries bordering the Gulf of Guinea, family farms traditionally supplied the local market with red oil while palm oil for export was produced by the agro-industries that had taken over from the former colonial plantations. A role identical to that played by the agro-industries in Southeast Asia was entrusted to State-owned companies in Côte d'Ivoire and Cameroon's national plans for oil palm development. Unfortunately, the ongoing process came to a standstill in the 1980s with the plans for structural adjustment and the privatizations required from States by the international financial system. The sector has not developed in line with population growth and today not a single country in the zone is self-sufficient in palm oil any more, let alone in a position to supply the international market (Jannot, 2014). But the countries in the area, and particularly those in the Congo basin, are of key interest to international investors. The region has the right agro-ecological conditions for oil palm cultivation and vast tracts of forest could be developed. Local people are already familiar with the crop and have a certain expertise and labor is relatively cheap. The countries of the region would like to accelerate their development and seek to attract international investors through tax exemptions and other advantages. The increasing difficulty of accessing land in Southeast Asia following the demands of environmental NGOs and proposed moratoria are also stimulating growing interest on the part of investors in diversifying their zones of production. Finally, closer access to the European and American markets makes it possible to cut transport costs. Since 2009, half a dozen companies have expressed interest in acquiring a total area of over a million hectares in Cameroon to develop oil palm plantations (Hoyle and Levang 2012). Similar requests have been received in most countries in the region such as Gabon, Republic of Congo (Congo-Brazzaville), Democratic Republic of Congo (Congo-Kinshasa), Liberia and Sierra Leone.

The current projects in the Congo basin are ideal for agro-industry and only rarely involve smallholders. However, an association of the two, following the model which has contributed to the success of the oil palm in Southeast Asia would be beneficial in economic, social and environmental terms. Economically speaking, the involvement of a large number of smallholders creates more jobs, both direct and indirect, and triggers an economic snowball effect which has a major impact on the reduction of rural poverty. The additional cost of involving smallholders (mainly transaction costs) is partly made up for by requiring smallholders to pay the cost of development through credit. On the social level, shared goals and development aid rather than competition and the exclusion of smallholders will boost social cohesion. Finally, on the environmental level, the development of plantations on peasant land, preferably on land that has already been cleared near villages and roads, means the equivalent area of primary forest is spared (Hoyle and Levang 2012). 
Current yields from village plantations are very low, on average less than a tonne of crude palm oil (CPO) per hectare per year in Cameroon, whereas the Indonesian smallholders are producing 4 tonnes, or even more than 5 when they are properly supervized. Ecological conditions differ, particularly in terms of rainfall, which is much more regular in Sumatra and Borneo. Apart from this, the low yields found in Africa are mainly due to the use of non-selected planting material, failure to replace plantations which have become too old, the almost complete lack of fertilization, poor maintenance of plantations and theft of bunches. The generally poor quality of the roads slows down the transfer of bunches to the oil mills and the marketing of the oil produced. If a carefully thought-out form of cooperation could be established between smallholders and companies, most of these bottlenecks could be eased, even better with the help of governments. At the moment, only the companies are in a position to obtain high-quality planting material from proper suppliers (or to take action in the case of obvious misselling). Companies alone are able to supply large quantities of agricultural inputs at competitive prices, or even on credit, to smallholders.

The involvement of companies is essential if bank loans are to be obtained to develop plantations approximating commercial standards, as well as to maintain them. Finally, in the absence of efficient public services, companies play a key role in maintaining the road network needed to move bunches swiftly to the oil mill (not to mention facilities such as schools and dispensaries). Production of standard quality oil and the guarantee of export sales usually means higher prices for smallholders. Hopefully, healthy cooperation between smallholders and companies will make it possible to tackle the problem of bunches being stolen and ensure social cohesion in the oil palm production area. Successful examples of this type of association also exist in Papua (Cramb and Curry 2012) and Colombia (Mesa Dishington 1998).

Oil palm cultivation can generate a high and stable source of income and support a rural middle class over several generations, something which few tropical crops can achieve today. For example, in Sumatra (Indonesia), the average annual income per hectare over the full cycle of a plantation comes to $€ 2100$ for palm oil, as compared to only $€ 200$ per hectare for a rice field. A comparison of the return on labor is even more striking: $€ 36$ per day per person for oil palms as against only $€ 1.70$ per day per person for irrigated rice (Feintrenie et al. 2010). In Indonesia, the NES project in general has been successful in reducing poverty. The number of poor people in NES areas is between 2 and $7 \%$ only and such figures are below the national poverty level of $14 \%$ (Drajat 2010).

Smallholders (whether independent or associated with agro-industrial complexes) are earning a fast-growing share of the market in Southeast Asia. Although smallholders in Indonesia were only offered a chance to participate in the crop after the end of the 1970s, they now farm about $45 \%$ of the planted area. In Thailand, about $76 \%$ of the total area of mature palm plantation was taken up by smallholdings in 2009 (Teoh 2010). 


\section{Choosing a development model}

Smallholders or agro-industries? Which is the best development model? This is the question politicians keep asking researchers. The quick answer is that this is not a technical choice. There is no doubt that agro-industries are often more efficient than family farming in terms of fruit and oil yield. Transaction costs are lower and State involvement may be limited to granting easy terms to investors. In addition, in terms of duties and taxation, monitoring compliance with environmental rules (such as the Roundtable on Sustainable Palm Oil [RSPO] certification or pollution control) or social standards (workers' rights), it is always easier to deal with a small number of big enterprises than thousands of unorganized or poorly organized smallholders. But, in terms of social justice, job creation and reduction of poverty, there is also no doubt that family farming has proved itself.

The choice of development model is therefore not a technical decision but a societal choice. What future do we want for our children? Do we want them to live the lives of independent smallholders or employees of agro-industries? Both options have advantages and disadvantages. And the choice we make may not be the choice our children would make. One thing alone is definite: the oil palm as a plant has nothing to do with it. 


\section{Palm oil and health: Fats and fiction}

\section{There is no such thing as the perfect vegetable oil}

No vegetable oil is naturally capable of supplying the perfect balance of essential fatty acids. Palm oil is no exception; its fatty acid composition is weighted towards saturated fatty acids with a clear predominance of palmitic acid (Figure 9).

Essential fatty acids come in two forms: essential fatty acids and non-essential fatty acids. Foremost among the non-essential fatty acids is oleic acid (the main monounsaturated fatty acid in our diet) and saturated fatty acids. The main saturated fatty acids are lauric, myristic and palmitic acid which are considered atherogenic when consumed in excess.

\section{It's the amount that counts}

Palmitic acid, although not considered an essential acid, is not a poison; it is a natural compound and is even found in breast milk. The accumulation of palmitic acid gave mammals a decisive evolutionary advantage until it came to the case of Homo sapiens in Europe and North America at the end of the 20th century. It is palmitic acid which helps the breast fed child to grow rapidly, barnacle geese to migrate by supplying their biological fuel, camels to cross the desert and marmots to hibernate. It is a key molecule which allows storage and concentration in a single compound of all the excess energy supplied by various different types of food.

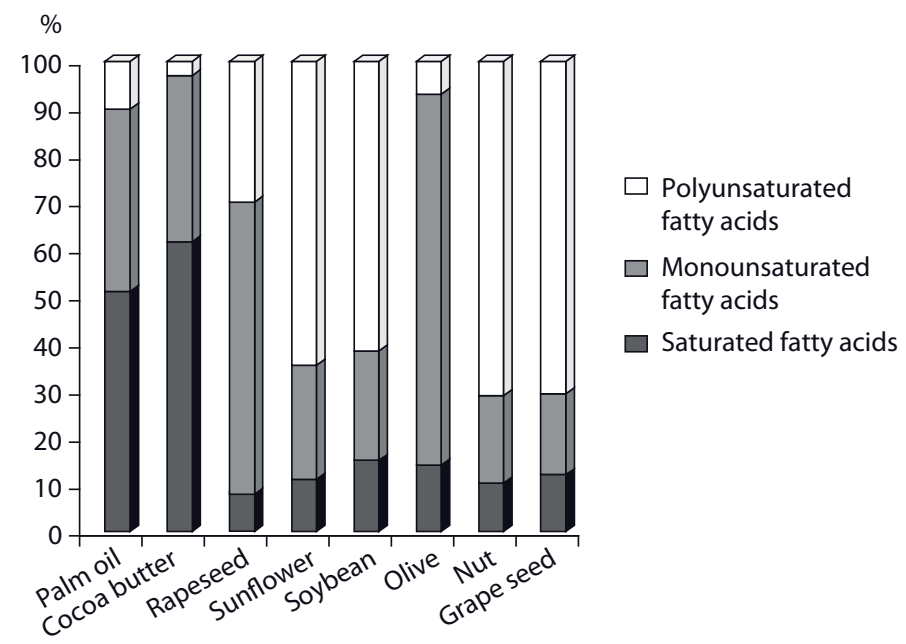

Figure 9. Fatty acid composition of main vegetable oils. 
Unfortunately, this key molecule role becomes a major drawback in situations of overconsumption. The hunter-gatherer, Homo sapiens, who evolved by carefully saving energy has become overfed and sedentary, a prime target for metabolic syndrome. ${ }^{4}$ Adding palm oil, which is rich in palmitic acid, to a diet and lifestyle which facilitates the accumulation of saturated fatty acids is obviously not to be recommended.

The situation is different in those countries in the South where the consumption of refined (palm olein) and unrefined (red) palm oil is part of a diet rich in fruit and vegetables, and short on meat (mainly for economic reasons). These societies still have a largely rural lifestyle, which is much less sedentary than that of industrialized countries. However, the situation is rapidly evolving; problems of obesity and cardiovascular disease linked to diet are beginning to appear for the first time in urban communities in countries such as China and Brazil.

\section{How real are these risks?}

The consumption of palm oil in France can be easily estimated from import statistics, although these vary considerably from one year to the next. About 126,000 tonnes per year for 60 million people gives the rough figure of $2 \mathrm{~kg}$ per inhabitant per year (FFAS 2012). This figure does not take into account the amount used in animal food, and most importantly, the quantity re-exported in the form of processed food: France exports a significant volume of these products. Experts tend to agree on a figure of $1 \mathrm{~kg}$ per inhabitant per year. In total, in the worst case scenario, palm oil accounts for $1 \mathrm{~kg}$ out of the $50 \mathrm{~kg}$ of fats consumed annually by the French, that is $2 \%$ for a regular consumer of frozen dishes, savory crackers and crisps, ready meals, cakes and manufactured confectionery. None of this consumption is compulsory!

Palm oil has only recently made an appearance in the Northern diet and is still little understood on the nutritional front (FFAS 2012). Conclusions as to the impact of its consumption on cardiovascular risk markers (mainly cholesterol and lipoproteins) must be qualified. Research results are often contradictory and hard to transpose from the animal model to humans. Epidemiological and clinical studies show that an extremely high intake of saturated fatty acids can, in certain cases, be linked to an increase in cardiovascular risk, but other studies show that this relationship is weak or non-existent. An analysis of prospective studies published in 2010 did not put forward any statistically significant relationship between saturated fat and the risk of coronary heart disease, cardiovascular disease and stroke (Siri-Tarino et al. 2010). More recently, Chowdhury et al. (2014) concluded from their review and meta-analysis that current evidence does not clearly support cardiovascular guidelines that encourage high consumption of polyunsaturated fatty acids and low consumption of total saturated fats.

4 Metabolic syndrome is the term for the combination of a series of physiological factors which increase the risk of diabetes, cardiac disease and stroke. 
The French Paradox does not help clarify the debate. This is the epidemiological observation that, despite considerable consumption of saturated fats in the form of butter, cream, cheese, eggs, liver, fatty meat and rich charcuterie (such as pâté and sausages), the French have a much lower rate of cardiovascular disease than Americans: 145 heart attacks per year per 100,000 inhabitants of average age compared to 315 in the United States.

Recent recommendations by the French National Agency for Food, Environmental and Occupational Health and Safety (Agence Nationale de Sécurité sanitaire de l'alimentation, de l'environnement et du travail) (ANSES 2011) limit the consumption of saturated fatty acids to $12 \%$ of overall energy intake, and of those fatty acids held to be the most hypercholesterolemic, including palmitic acid, to $8 \%$.

But in considering this, we must not forget that increases in cholesterol levels are multifactorial and do not rely on consumption of a single type of fatty acid. Furthermore, scientists remain very cautious about the classification of essential and non-essential fatty acids. The physiological role of a number of fatty acids remains little known and it is sensible to consider that their presence in the modern human organism after 40,000 years of evolution is not just pure chance. For example, myristic acid, held to be atherogenic when in excess in the human body, is also an essential constituent of cell membranes and therefore directly involved in cell ageing.

\section{Label, substitute or boycott?}

Refined palm oil, which is mainly used as a solid fat at room temperature, will never supplant traditional oils (olive, sunflower and rapeseed) at the European table. Before being consumed it will have gone through the same process as other lipidrich industrial preparations, so limiting consumption of this type of food should allow those who consider it hazardous to significantly cut their consumption of palm oil. Our grandparents and parents brought us up without a gram of palm oil and no doubt we can continue to do the same as long as we can clearly identify, and if we wish, avoid processed goods which contain it. It must be borne in mind that the term 'balanced diet' applies to overall diet and not each food item taken separately. Cutting out chocolate spread rich in palm oil and replacing it with vegetables dressed with groundnut oil will not significantly alter your consumption of saturated fatty acids.

To obtain the same physical and chemical properties as palm oil from largely unsaturated vegetable oils, it is necessary to partially hydrogenate these oils. This process involves the formation of trans fatty acids (trans fats) which are neither necessary nor healthy to consume in comparison with natural fatty acids (saturated or unsaturated). Regular consumption of these acids increases in particular the risks of cardiovascular disease, even at a low dose, as well as breast cancer. These natural characteristics of palm oil enable to cut back on partial hydrogenation of vegetable fat and consequently the production of trans fats. Replacing palm oil should not be allowed to lead to the use of partially hydrogenated vegetable fats which are the source of trans fats. 
The term 'vegetable oil' has long been adopted by food-processing industry in order to be able to use a single label. Vegetable oils used to vary constantly in terms of availability and price, and this general label enabled processors to shift from one vegetable oil to another without having to alter the labelling on the finished product. Over the last 10 years, palm oil, which is both abundant and cheap, has become the sole source of vegetable oil for the majority of agro-industrial applications such as biscuits, prepared meals and frozen food. This means that today there is no longer any technical reason not to clearly label the presence and concentration of palm oil in manufactured products. The reasons are no doubt to be found in short-term marketing strategies designed to reassure consumers who are already aware and often mistrustful thanks to the explicit NGO campaigns. This lack of detailed information has a boomerang effect on public opinion. Why are we being kept in the dark about the presence of a product if it is harmless? What is the real rate of concentration? Can we really do without it, and at what price in socio-economic, health and ecological terms?

Labels describing the type of vegetable oil incorporated into food products together with their proportion will become compulsory from 13 December 2014, when the European Food Information Regulation, published on 22 November 2011, will come into full effect. ${ }^{5}$

Consumers in the North have already shown that they can raise standards in the sector by requiring that processors, at the very least, comply with existing standards on sustainability (weak as they are). From now onwards, we need to promote and encourage use of RSPO certified oil (or oil subjected to other more stringent standards, where available and verifiable). Under consumer pressure, many manufacturers and major retailers in the North have agreed to switch to $100 \%$ certified oil by 2015, which represents very significant progress. The recent establishment of the French Alliance for Sustainable Palm Oil (Alliance Française pour l'Huile de Palme Durable), following similar steps taken in Belgium, Germany, the Netherlands, and the United Kingdom, underlines this commitment.

Stocks of palm oil are very low ( $<8 \%$ of production in 2012) and demand is maintained by countries with high economic and demographic growth.

This means that withdrawing from the market the $17 \%$ destined to meet the needs of the North (if we include biofuel) will have the effect of re-inflating supply, by bypassing any certification constraints, which do not exist in the markets of the South. The effect will be the opposite of that sought; non-RSPO certified palm oil will be indirectly encouraged.

Boycotting palm oil will also serve to boost the production of other vegetable oils of different chemical composition, often genetically modified and not necessarily more ecologically or socially acceptable, bearing in mind their low yield per hectare and the need for intensive application of pesticides in their cultivation.

5 EU Regulation $\mathrm{N}^{\circ} 1169 / 2011$ of 25/10/11 - O.J. EU L304,22/11/11, p.18-63 
Developments in France in 2012, such as the Nutella Amendment or the action brought against the French retail chain Magasins $U$ by the The Interprofessional Association of Palm Oil Producers from Côte d'Ivoire (Association interprofessionnelle des producteurs de l'huile de palme - AIPH - Côte d'Ivoire) showed that it was dangerous to stigmatize a sector, even one based in the tropics, and therefore theoretically deprived of lobbyists in Europe, without being familiar with the origins, mechanisms and actors involved. These were the final episodes of an 'oil war' which had been waged for over 30 years. To appeal to the prejudices of consumers in the North in order to condemn an entire sector based in the world's tropical zones while protecting national interests has rarely proven to be a productive strategy (Berger 1995). The American soybean lobby had already paid the price during the 'oil war' of the 1980s when tropical oils as a whole were the subject of lengthy vilification by organizations set up for the purpose. ${ }^{6}$ A full page advertisement in the New York Times of 1 March 1989 published under the heading 'The Poisoning of America' singled out American firms using palm oil for public opprobrium. Worried about the role of the United States as opinion shapers rather than as importers, the Malaysian government decided to respond to this campaign on scientific grounds. The Palm Oil Research Institute of Malaysia (PORIM, now MPOB for Malaysian Palm Oil Board) launched a research program on the nutritional properties of palm oil, with the participation of internationally renowned European and American laboratories. The results of these investigations, which were obtained by using abnormally high levels of palm oil or palm olein in the daily food of people from both east and west, proved beyond doubt that these products have no negative effect on blood lipids (Berger 1995). An institution from the South had shown that it had the means to prove that the 'arguments' of the American programme of vilification were without scientific basis. Unfortunately, the deed had been done and this campaign opened the door to large-scale incorporation of trans fats in American food, until the introduction of recent regulations, at least in certain states and in New York City.

Our consumption of different vegetable oils has followed changes in our eating habits. While the pattern of intake in the northern hemisphere remains varied, with overall consumption stable or even dropping, consumption in the newer countries has soared in a generation from 5 to $15 \mathrm{~kg}$ of oil per inhabitant per year. This development is accompanied by qualitative changes, linked to the switch from consumption of vegetable oils with different saturated and unsaturated fat content to $100 \%$ palm oil and a trend towards an increasingly urban, sedentary lifestyle. This is no doubt a factor to watch for in the future. We can only hope that once urgent and essential needs for lipids are met, the people of India, China or Indonesia will have access to a range of sources of fat comparable to those on offer to shoppers in the North today.

6 The Center for Science in the Public Interest or The American Heart Savers Association 


\section{Towards a sustainable form of production}

\section{Must the forest be sacrificed?}

As the World Wildlife Fund (WWF 2011) stresses, the major challenge we face is to shift from deforestation to sustainability. While it cannot be denied that the socio-economic impact of oil palm expansion has been positive rather than negative it is equally true that its environmental impact has been disastrous. In Southeast Asia, in particular, this expansion has been mainly to the detriment of the humid tropical forest, one of the world's most extraordinary reservoirs of biodiversity. In the span of a few decades, Indonesia has seen the conversion of more than 5 million hectares of primary forest, Malaysia over 4 million, Nigeria 1 million, and about the same amount has been converted in the rest of the world. The conversion of primary forest into monospecific oil palm plantations is undoubtedly an ecological disaster. After the bulldozers have been through and the land has been burned, little is left of the biodiversity of fauna and flora, nor of the habitats of the innumerable species living in the forest. Orang-utans, gibbons, tigers and elephants are often in the headlines but the damage extends well beyond these few emblematic species.

Environmental NGOs are right to emphasize this negative aspect of oil palm expansion. However, as we have underlined several times, the oil palm - as a plant - bears no responsibility for this. We should remember that E. guineensis originated in the great tropical forest bordering the Gulf of Guinea and that it occupies a modest place in this rich biodiversity. The problem is not the oil palm but the way people have chosen to exploit it. The palm tree is just the vehicle, the real problem is the conversion of the forest for agricultural use, particularly where this use takes the form of a monoculture. Be it oil palm, soybean, sunflower, rapeseed, sugar cane or Acacia mangium, the problem remains the same: the forest with its rich biodiversity is sacrificed. It makes little sense to boycott palm oil if in replacing it you convert eight times more forest into soybean and sunflower fields. This happens to be one of the favorite arguments of the palm oil industry: Because yields of oil palm are eight times higher than those of soybean, we can reduce the surface area which needs to be deforested. But the argument is misleading neither soybean nor oil palm require deforestation.

The appeal of the forest to big palm oil producing companies comes down to two things: the relatively free access and the timber. Few countries recognize their citizens' rights of ownership — or even usage — of primary forest, let alone the rights of indigenous forest people who are often considered as second-class citizens. Refusal to recognize the customary rights of forest peoples is very widespread in tropical areas. In general, forest management is entrusted to centralized State services (Forest Ministry, Forest Services) responsible for their conservation and 
exploitation and possibly for authorizing their conversion. It is relatively easy for a company to obtain a vast concession of primary forest to convert into a plantation from a few civil servants who are not always pillars of probity. To secure land in an area which has already been cleared they would need to negotiate with a multitude of smallholders, which would add considerably to the cost of the transaction. Possible rejection by any of these would produce a series of enclaves, preventing the establishment of large-scale homogeneous blocs. The availability on site of a large amount of wood or biomass is another attraction. Where authorization is given for lumber to be exploited, this can cover a large part of the costs of the operation. If not, slashing and burning a significant amount of biomass can bring down the cost of fertilization and control of weeds in the early years. In the worstcase scenario, the establishment of an oil palm plantation can just be an excuse for unscrupulous entrepreneurs to gain access to timber resources. A project to plant oil palms, which in theory is very profitable, can also serve as a guarantee to obtain the bank loans needed to exploit the forest. Towards the end of the 1990s, several million hectares of Indonesian forest were apparently destroyed in this way, on the pretext of developing oil palm plantations.

\section{Plantations and sustainable development}

However, there are several ways in which oil palm plantations can be developed without destroying vast stretches of tropical forests in the process. These include agro-forestry techniques, patchwork developments and ecological planning. Each of these solutions has its own advantages and disadvantages.

\section{Agro-forestry techniques}

Agro-forestry techniques are well known in the countries bordering the Gulf of Guinea. The forest peoples of the region began by exploiting the palm trees growing spontaneously in the forest and scrubland which developed after clearing. Bit by bit, they created vast sub-spontaneous palm groves by protecting and encouraging the development of the most productive specimens through the process of mass selection. Specimens producing little fruit were sacrificed to produce palm wine. As the international market for palm oil grew, farmers in the region started to plant palm trees on cleared land near villages. These palms were generally planted in combination with other crops such as cocoa, coffee and other fruit. Over time these agro-forests often developed into secondary forests and could return in the slash-and-burn system of cultivation. The level of biodiversity which results from this technique far exceeds that of a monoculture but is it is still well below that of a primary forest. At the economic level, the system guarantees the supply of numerous products and services needed in village households such as palm oil and palm kernel oil, palm wine, materials for crafts and building, to mention but a few of the vast range of items derived from Elaeis agro-forests. But beyond meeting domestic needs within households, agro-forests struggle to produce enough monetary income. Generally speaking, the amounts derived are not sufficient to establish real marketing networks. Retailers and middlemen are 
unwilling to make a journey for small quantities of widely varying products, and as the costs of gathering it are high, prices offered to sellers are not very attractive. Only a few products from the agro-forests, such as palm oil, appeal to traders. As a result, farmers naturally tend to favor those agro-forest products which bring in the most monetary income. If monetary needs grow, which is the case throughout the tropical zone, farmers will even tend to get rid of all the species which are less economically viable despite the fact that these make up the richness of the system's biodiversity. To put it plainly, the way to improve the economic profitability of the agro-forest is to simplify. In the long run, taking this logic to its extreme, the agro-forest would become a monoculture. In reality, change is faster and less gradual. Faced with a rapid change in outlook (following the opening up to the outside world, improvement of infrastructure and appearance of radios, televisions and telephones) and the example of the high-yielding monospecific plantations, smallholders will waste no time in sacrificing their agro-forest and replacing it with an oil palm plantation, provided, of course, that they have the means.

Many researchers, both agronomists and socio-economists, won over by the sustainable nature of agro-forests ${ }^{7}$ have tried to pre-empt what appears to be an unavoidable progression sweeping through most tropical parts of the world. To improve the economic profitability of the agro-forests, agronomists are trialling viable associations of several economically attractive species. These studies are still underway, but promising results have apparently been obtained for associations of oil palms and cocoa plants planted in conjunction with a few lines of fruit trees. The main problem is the strong shade produced by palm fronds which does not help in companion planting and makes it necessary to considerably reduce the density of palms. However, even if research manages to develop economically viable associations, the biodiversity of these systems remains very low in comparison to primary forest. In any case, these systems can only be developed on land which is already agricultural. There is always the danger that economically profitable systems, even of the agro-forest type, will induce local people to make more agricultural land out of the adjacent forest.

Social sciences have a considerable amount invested in their desire to save agroforest systems from disappearing. Their approach differs from that of agronomists because they seek to replace the economic shortfall of agro-forests in comparison with monospecific plantations by paying a premium for environmental services rendered. In return for not replacing their agro-forest, peasant farmers are offered compensation which is designed to make up for the shortfall and recompense them for maintaining a high level of biodiversity in their plots of land. Several experiments have been carried out in rubber agro-forests in Sumatra. Instead of paying a direct annual bonus to owners of agro-forests, it was decided to add a premium to the price of rubber derived from agro-forests. As applies to all payments for environmental services ( PES), there are numerous obstacles to its

7 There were still over 3 million hectares of rubber agro-forests on the island of Sumatra in Indonesia towards the end of the 1990s (Gouyon et al. 1993; Feintrenie and Levang 2009). 
implementation, such as knowledge of the extent of the agro-forest at the beginning of the project, and then its evolution over time, area owned per smallholder, and, above all, how to ensure that the subsidized rubber really comes from an agroforest. But for project developers, the main difficulty lies in finding an institution or company which would be ready to finance such a payment on a sustainable basis. So far, despite repeated appeals to the environmental goodwill of tyre manufacturers, no factory owner has agreed to pay $50 \%$ more for rubber derived from agro-forests. And this is before taking into account the fact that agro-forest rubber is often of poorer quality than the more homogenous product obtained in clonal industry plantations.

\section{Patchwork developments}

Patchwork developments are in some ways a reflection of change in areas which were formerly mainly agro-forests. Here, diversity is neither deliberate nor managed. It simply reflects the range of socio-economic situations of the households found within it. Monospecific plantations are juxtaposed with agro-forests (which are dotted through forest clearings of various ages), plots growing food crops, shrubby fallow land and even islands of primary forest. The countryside is constantly changing shrubby fallow land becomes a food plot, the latter is then set aside, agro-forest is replaced by a clonal plantation and old plantations are invaded by wild species. The cycle of slash and burn follows the lifecycle of the heads of household. Young people take jobs as laborers or tenant farmers working with older farmers. Once married, they create their own plantations and enjoy the fruit of their investments when they retire. The wild fauna also benefits from this diversity in the landscape. A varied range of niches exists, from intensively cultivated food crops to set-aside land and former fallow land, although the fauna in question mainly comprises rodents, birds and reptiles of all sorts. There is barely enough space for large mammals such as tigers, rhinos, elephants and large primates.

\section{Ecological planning}

The third option, ecological planning, which numerous observers pin their hopes on, is similar to this idea of a patchwork effect but is more tightly organized and controlled. Here, the objective is not to preserve the forest as a whole but rather to limit the worst effects of conversion. Following where possible the precepts laid down by RSPO, a system of planning aims to prevent those zones recognized as of high conservation value (HCV) or of High Carbon Stock (HCS) from being converted. The same applies to areas near rivers, hill tops and very steep slopes. Only part of the countryside is converted into plantations. Great care is taken to connect the different conservation zones. Where necessary, agro-forest zones serve as buffers between conservation and plantation zones. This model was recently tested in Malaysia and Indonesia by a few companies keen to improve their environmentfriendly image. There is an underlying economic motive: Being awarded certification implies respect of the highest environmental standards and the shareholders of big multinationals are increasingly concerned about the social responsibility of their firms. In addition there is a real risk that the public might boycott palm oil 
following campaigns by ecological movements. Unfortunately, there is a range of factors which serve to hinder the spread of this system of ecological planning. First and foremost, implementation requires a degree of technical knowledge still rarely available in the companies active in the field. It also entails a substantial additional outlay which is by no means made up for by the benefits of certification. Finally, the financial and legal incentives are still too low for most companies. The market dominated by the emerging countries is more interested in cheap oil than 'clean' oil and the weak governance in most of the countries where the major companies are active tends not to respect legislation (when this exists at all).

All commentators agree that the palm oil business is going to go on growing for several decades to come. This growth will be in part to the detriment of tropical forests. In Central Africa, in particular, it is wishful thinking to try to maintain forest cover at its current level. The priority of both government and people is to make up their development deficit, not to maintain or extend conservation zones. The challenge is not so much to prevent expansion of the palm oil sector but to encourage forms of development which seek to keep negative impact on biodiversity and the well-being of local people to a minimum.

In Indonesia, the Palm Oil Timber Carbon Offset (POTICO) ${ }^{8}$ project of World Resources Institute, a US NGO, aims to redirect oil palm plantation projects, originally planned for forests, to 500,000 hectares of degraded land, by organizing land exchange. The areas which were originally planned as palm plantations will be conserved or exploited to produce Forest Stewardship Council (FSC) certified wood.

However, there is an argument to be made that before we sacrifice more primary forests we should intensify production in zones which have already been converted into palm plantations. Despite its favorable agro-climatic conditions, Malaysia has an average national yield of less than 4 tonnes per hectare, which remains far below the top yields achieved in some plantations in the region (6-7 tonnes per hectare). Africa offers particularly dramatic margins for progress. In Cameroon, for example, the average yields of smallholder plantations are only a quarter of the average yield of Indonesian smallholders.

\section{Ecological intensification}

Areas already planted with oil palms often fall well short of producing the yields of oil expected (3.7 tonnes per hectare as a global average while selected plant material used in trials produces more than 10 tonnes per hectare under optimum ecological conditions). It is, therefore, important to optimize the production system of existing palm plantations while keeping the impact on people and the environment to a minimum. 
Ecological intensification of productivity means first and foremost ensuring all planters - both smallholders and agro-industrial estates - have access to selected and certified seeds, so more people can benefit from the latest genetic breakthroughs made by research. The adoption of improved seeds adds value at all stages of oil production and primary processing. Investing US\$ 1 in an oil palm seed originating from best hybrids will provide an average income of US $\$ 1300$ by the end of its 20 years of exploitation. Improved planting material provides the planter with higher yields in terms of bunches and optimizes labor (through easier harvesting of shorter palms). It helps the factory owner by offering better extraction rates and the refiner by increasing olein content. By providing better resistance to disease and making it possible to use the same land for several generations, genetic selection and the availability of selected hybrid seeds help reduce pressure on land, particularly since yield also rises. Genetic progress for the oil palm has been measured at $1-1.5 \%$ per year (similar to maize) which makes a significant contribution to ecological intensification. However, this alone is not enough to meet increased needs for vegetable oil $(+3-4 \%$ per year) and for palm oil in particular $(+5-6 \%)$. Best agricultural practices should also be adopted to contribute to this intensification, which is designed to meet global demand by limiting the area under cultivation.

Ecological intensification also relies on the implementation of well-planned fertilization, both for economic reasons (fertilizers account for over $60 \%$ of the running costs of a palm plantation) and out of respect for people and the environment. Fertilizers made from petrochemical products or non-renewable mineral sources have a limited future. The challenge is therefore to optimize the use of fertilizers (mineral and organic) to ensure they provide maximum benefit to the plant through divided and well-planned applications that avoid any surplus leaching into ground or surface water. These needs are assessed from mineral analysis of soil and leaf samples taken in the plantations. Analysis provides thresholds for fertilizer use depending on climate, plant physiology, soil type and the genetic origin and age of plantation.

This type of environment-friendly management is not a new concept. It has developed in recent years with the growing awareness of the need to combine high yields with environmental protection.

On average, over the economic lifetime of a plantation (20 years), around $850 \mathrm{~kg}$ of fertilizer are applied per year per hectare. The use of compost made from the stalks and liquid effluents from of oil mills enables a very significant reduction in these inputs. By way of comparison, the cultivation of soybean requires about $150 \mathrm{~kg}$ of mineral fertilizers per hectare per year; soybean is a legume which can fix atmospheric nitrogen so it requires less nitrogen fertilizer. However, if we work out the rate of application needed per tonne of oil for average respective yields of 0.6 tonnes per year and 4 tonnes per hectare we get the figure of $250 \mathrm{~kg}$ of fertilizer per tonne for soybean as compared to $213 \mathrm{~kg}$ per tonne for oil palms, rates which are comparable. Similar figures are obtained for another temperate oil crop, rapeseed, namely $230 \mathrm{~kg}$ per tonne of vegetable oil. 
Major headway is being made in composting organic waste and recycling oil mill effluents. Almost all the biomass and by-products generated in plantations and oil mills can be recycled and used as organic fertilizers. This includes the pruned fronds as well as empty bunches and liquid effluents of oil mills. This practice is now an integral part of fertilization management plans, mainly in industrial plantations; inputs from inorganic fertilizer can be cut by nearly $15 \%$. Some of the recycled products improve not only fertility but also the texture of the soil. The combination of inorganic and organic fertilizer (derived from recycling or composting) is managed differently from plantation to plantation, according to the specific needs of the plot of land, as the application of organic fertilizer alone is not always sufficient to maintain soil fertility.

The use of lagoons for the decanting of liquid effluents produces methane, a gas which has a strong greenhouse effect and is now used to supply biogas around oil extraction plants. This is a way of harnessing the considerable energy potential of organic by-products $\left(12 \mathrm{~m}^{3}\right.$ of methane per tonne of fruits extracted, $15 \mathrm{~m}^{3}$ of methane per $\mathrm{m}^{3}$ of liquid effluents). Each $1 \mathrm{~m}^{3}$ of biogas generated enables the equivalent of 0.56 litres of diesel to be produced. This practice is spreading rapidly in a large number of plantations, and new installations are now equipped at the time of construction for biodigestion of effluents and biogas capture. The transportation of this excess energy remains problematic because plantations and oil mills are often very isolated geographically from the distribution networks and sometimes have to settle for burning their surplus biogas in flares.

In Indonesia alone, at the level of 2012 palm oil production, the biodigestion of palm oil mill effluents can produce approx. 3.3 million MWh per year. This can reduce use of diesel oil by 1.3 million kiloliter per year, which is around $4 \%$ of the annual diesel import volume, and thus can save between US $\$ 1$ billion to $\$ 1.3$ billion of foreign exchange reserve per annum.

The use of pesticides in oil palm cultivation is restricted to limited applications of herbicides in young plantations to control the growth of cover plants and to create paths for harvesting. In some areas, particularly in Southeast Asia, use of rat poison is common, although this is increasingly being replaced by the introduction of barn owls (Tyto alba), their natural predators.

Although all progress achieved in this area is useful, the use of pesticides is not a real obstacle to the sustainable exploitation of oil palms as these inputs are used in much smaller quantities than on other oil crops, which means pesticide limitation is not a priority. When quantities of pesticide per category are compared between soybean (Brazil) and oil palm (Indonesia) the results speak for themselves: $5.8 \mathrm{~kg}$ of equivalent active pesticide materials are applied per hectare per year on a soybean crop as compared to $0.4 \mathrm{~kg}$ per hectare per year for oil palm. The differences become even more marked if we calculate the amount of pesticide applied per tonne of oil extracted. Taking an average yield of each respective oil of 0.6 tonnes per year and 4 tonnes per hectare, we get $10 \mathrm{~kg}$ per tonne for soybean compared to $0.1 \mathrm{~kg}$ per tonne for oil palm, that is 100 times less pesticide applied for the same quantity of vegetable oil produced. 
The role played by pesticides in the running costs of an industrial palm plantation is below $1 \%$, as compared to $50-55 \%$ for fertilizer costs and $30 \%$ for harvest costs.

Table 1. Amounts of pesticides used in cultivation of soybean and oil palm (kg/ha/year)

\begin{tabular}{lcc}
\hline Pesticides & Soybean & Palm oil \\
\hline Herbicides & 4.2 & 0.41 including Paraquat 0.1 \\
\hline Raticides & 0 & 0.001 \\
\hline Fungicides & 0.55 & $<0.001$ \\
\hline Insecticides & 1.0 & 0.001 \\
\hline Total & $\mathbf{5 . 7 5}$ & $\mathbf{0 . 4 1}$ \\
\hline
\end{tabular}

To date there have been no major endemic diseases affecting oil palms which could not be treated biologically.

Fusariosis, caused by the soil fungus Fusarium oxysporum, was eradicated in some areas of infestation in Western Africa through the introduction and wide-scale use of resistant seeds developed through traditional plant breeding programs. To counter attacks of the fungus Ganoderma in Southeast Asia, current research is investigating the same genetic control strategy, based on sources of natural resistance. In the same vein, the fight against bud rot (an extremely virulent complex of pathogens) in Latin America is based on the genetic resistance displayed by the Amazonian palm, E. oleifera. What this means is that in the three continents of oil palm cultivation there are three major diseases which for the time being remain largely confined to their geographical origins. Oil palm breeders and growers just hope this will last for a long while...

The ecological intensification of oil palm cultivation comes up against the biological constraints of the plant which make production difficult to mechanize and therefore relatively demanding in terms of labor (one person per 10 hectares on average).

Oil has to be extracted promptly from the fruit to avoid losing its physical and chemical properties. This requires an efficient harvesting network, maintained infrastructures and reliable organization of the harvesting areas around mills.

The transfer of innovation to smallholders remains one of the main challenges facing ecological intensification. If these planters can be organized into national projects or public and private sector associations, the transfer of innovation (selected seeds and best agricultural practices) is relatively easy and swift; the organizational structure offers the necessary credit facilities and technical and financial support. Independent planters who are not grouped together in cooperatives remain harder to reach, and therefore convince, in spite of the enormous gains in yield to be achieved. 


\section{Roundtable on Sustainable Palm Oil (RSPO) initiative}

When it was launched in 2004, RSPO was a business-to-business initiative bringing together about 10 members, both private actors in the industry (such as Unilever) and NGOs (such as WWF). It is an international, multi-stakeholder initiative to certify and promote sustainable palm oil.

In November 2005, eight principles and 39 criteria for certification were approved, leading to certification of the first plantations in 2008. The first Certified Sustainable Palm Oil (CSPO) was sold at the end of 2008.

Today, the Roundtable has reached 1500 members, divided into seven categories: growers, processors and traders, manufacturers, banks and investors, retailers, environmental/nature conservation NGOs and social/developmental NGOs.

The Roundtable has various working groups through which it carries out, diversifies and enhances its activities. National or regional interpretation groups are responsible for integrating the certification principles and criteria into national legislation. There is still some way to go before they are adapted to the specific constraints of family farmers; the cost of certification and corrective action, estimated at US\$ 20-40 per hectare is often prohibitive for smallholders who are barely, if at all, organized into cooperative arrangements (WWF 2012a).

Today, 2.2 million hectares of plantations are RSPO certified, that is about $15 \%$ of the global surface area planted (as compared to 106,000 hectares in 2008) and 10 million tonnes of palm oil certified as sustainable were produced in 2013 $(620,000$ tonnes in 2008).

Like a large number of multi-stakeholders initiatives devoted to the promotion and standardization of a sustainable product (Forest Stewardship Council, Marine Stewardship Council, Round Table on Responsible Soybean, BonSucro), the RSPO receives considerable criticism. It is based on the voluntary acceptance, by consensus $^{9}$ of all members, of its principles and criteria and is therefore considered not rigorous enough and lacking in power (Laurence et al. 2010; Angerand 2011). The fact that RSPO certification is unable to protect the rights of indigenous people in terms of land rights, compensation for land annexation and respect for customary law has also been highlighted. As happened in the case of Forest Stewardship Council (FSC) certification for timber, the RSPO principles and criteria, which were designed to be consensual and universal, have become very difficult to apply and therefore of limited use in complex local contexts, like in Indonesia, where land ownership conflicts are not settled by the State but at district level This means that on one side we have a set of directives based on the logical approach of the North and on the other we have a local authority

9 For more on the modalities of decision-making by international bodies, based on those in use in the United Nations, see in particular De Lacharrière (1968). 
which may have little awareness of questions of sustainability, feels the pressure of development and is therefore in a precarious position. Negotiations are necessarily unbalanced and the process of certification does not succeed in protecting the rights of indigenous people. This puts the credibility of the whole process of certification at stake (McCarthy 2012).

Its detractors criticize the RSPO for the lack of participation by governments from the moment the Roundtable was set up. Ironically, it is the public authorities in each country which have the task of translating the RSPO Principles and Criteria into legislation in conformity with their respective constitutions. They are also responsible for applying these laws effectively in the field and of enforcing sanctions against offenders. It is all well and good to draft a highway code but it is not worth the paper it is written on if there are no unbribable policemen at the side of the road, responsible for ensuring that it is respected!

Finally, the market share of certified crops remains limited even if, as in the case of oil palm, it is growing rapidly. To date no more than $2.5 \%$ of world cane sugar is BonSucro certified, as compared to $16 \%$ of palm oil sold under the CSPO label. In the case of palm oil, the paradox lies in the fact that many processors and distributors in the North only committed themselves to using 100\% CSPO certified oil by 2015 when they could be doing it right now because about half $(48 \%)$ of the certified oil available on the market is not being bought up (Figure 10). The goodwill expressed by consumers is taking its time to bring about change in the supply chain of processors and distributors in the North. There is no denying that the supply network is extremely complex. The first positive impact of certification has been to map and identify the networks of suppliers

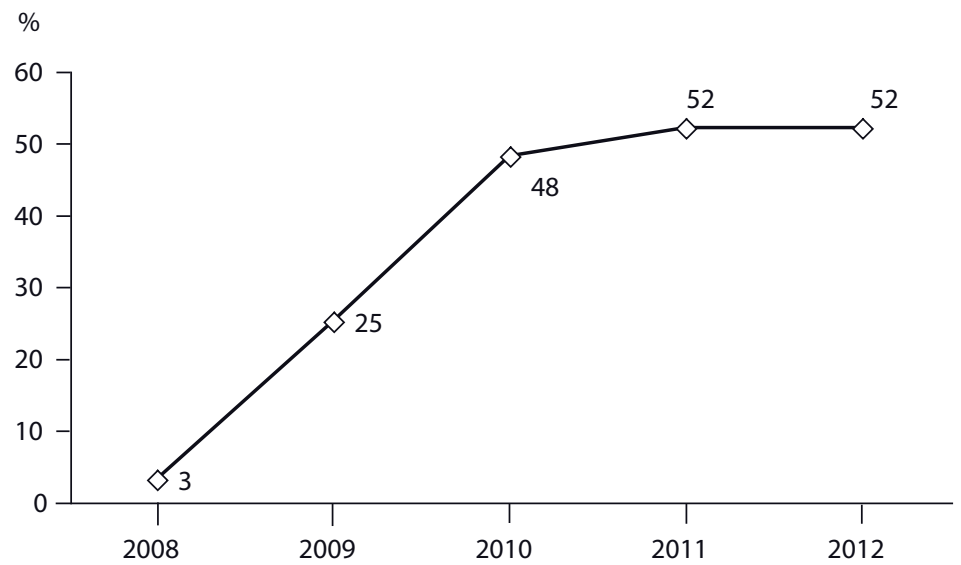

Figure 10. Evolution of the real uptake of certified palm oil put on the market. Source RSPO. 
and intermediaries. There are many lessons to be learned from the recent work carried out by Nestlé and The Forest Trust in this area. In 2010, a campaign by Greenpeace which was very persuasive and visually violent compared a KitKat chocolate bar with the bloody fingers of an orang-utan, accusing Nestlé of destroying tropical forests and their biodiversity. Nestlé then entered into a partnership with a specialized NGO, The Forest Trust, which was to help it develop a completely sustainable supply chain. The partnership lead to guidelines for sustainability (Responsible Sourcing Guidelines) which are specific to palm oil and establish the principle of traceability back to the plantation. A considerable amount of work has been done to map suppliers and intermediaries. The strategy is based on assessing the performance of suppliers in order to exclude those who participate in deforestation, and on providing technical support to suppliers who wish to implement the sustainability guidelines. In February 2011, in collaboration with The Forest Trust, the Indonesian group Golden AgriResources, one of the main Nestlé suppliers and a target of Greenpeace, set up a forest conservation program designed to protect high conservation value forests and peat bogs. Nestlé undertakes to use $100 \%$ CSPO certified palm oil in its supplies by the end of 2013 (still mainly through the purchase of Greenpalm certificates).

In addition, some RSPO members make much of the confusion between the concept of affiliation, which is a form of voluntary adhesion to the Roundtable agreement with its general principles, and the concept of certification itself resulting from a process which is standardized and validated by an independent certifying body and alone confers the right to use the registered trademark RSPO.

\section{The eight principles of RSPO certification}

\section{Commitment to transparency}

2. Compliance with applicable laws and regulations

3. Commitment to long term economic and financial viability

4. Use of appropriate best practices by growers and millers

5. Environmental responsibility and conservation of natural resources and biodiversity.

6. Responsible consideration of employees, and of individuals and communities affected by growers and mills

7. Responsible development of new plantings

8. Commitment to continuous improvement in key areas of activity. 


\section{Supply of certified sustainable palm oil}

Today's processors have a choice of four different strategies for obtaining CSPO certified sustainable oil, which differ in terms of strictness and cost of implementation. The price of certified oil is fixed according to supply and demand. The producer's premium depends on the certification system used by the supply chain. On average, US $\$ 1$ per tonne goes to the RSPO and $\$ 2$ per tonne cover administrative expenses.

For the end consumer, the wording of the label is not impartial and can cause some confusion: In some cases the product bought may only physically contain a limited amount of certified sustainable palm oil.

This is also the case in other certification schemes, for example FSC labelling which, for mixed sources only guarantees a 'Group of products from wellmanaged forests and other controlled sources...', a markedly vague concept even for the informed consumer.

Processors have four possible strategies, as set out below.

\section{Book and claim}

Producers and retailers incorporating palm oil in their products bid on-line for Greenpalm certificates and, through RSPO, pay a premium directly to the producers designed to encourage sustainable production and finance the certification of new members. The Greenpalm certificates do not claim that the product contains raw material which has been produced sustainably but that its use supports sustainable production. These certificates show the commitment of retailers to sustainable production at the beginning of the production chain. The retailers can state this on their declaration of social responsibility, their packaging, at their point of sale and on their internet site.

\section{Wording of label}

'Contributes to the production of certified sustainable palm oil, www.rspo.info' 


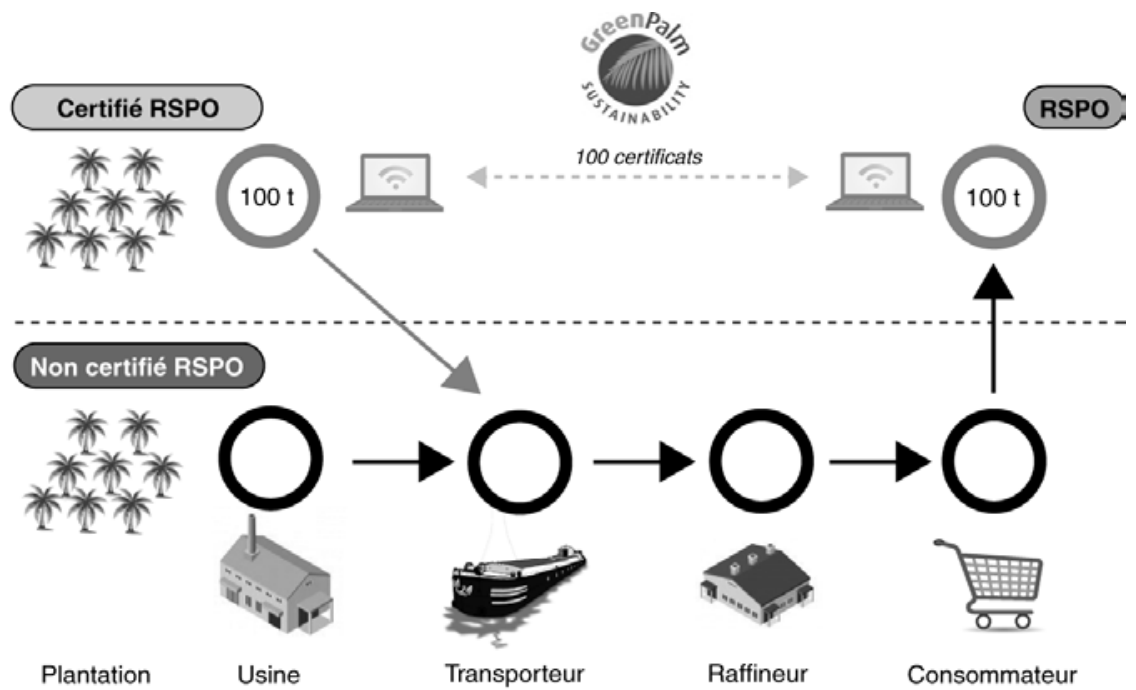

Figure 11. RSPO certification, book and claim.

\section{Mass balance}

Overseen by UTZ Certified ${ }^{10}$, this certification corresponds to the use of a mixture of sustainable and non-sustainable palm oil at any stage of the supply chain, providing global quantities at the company level are checked. The model is set up in such a way that the amounts of CSPO palm oil which leave the plantation never exceed the quantities received by the consumer. The purchase and sale of CSPO oil and its by-products are checked independently. There is no requirement for separate storage or verification in the production process.

\section{Wording of label}

'Mixed - Contributes to the production of certified sustainable palm oil, www. rspo.info www.rspo.org'

10 UTZ Certified is a programme of certification and a worldwide label for production, sales and processing. UTZ Certified guarantees the implementation of good agricultural practices and compliance with sustainable and traceable production conditions. 


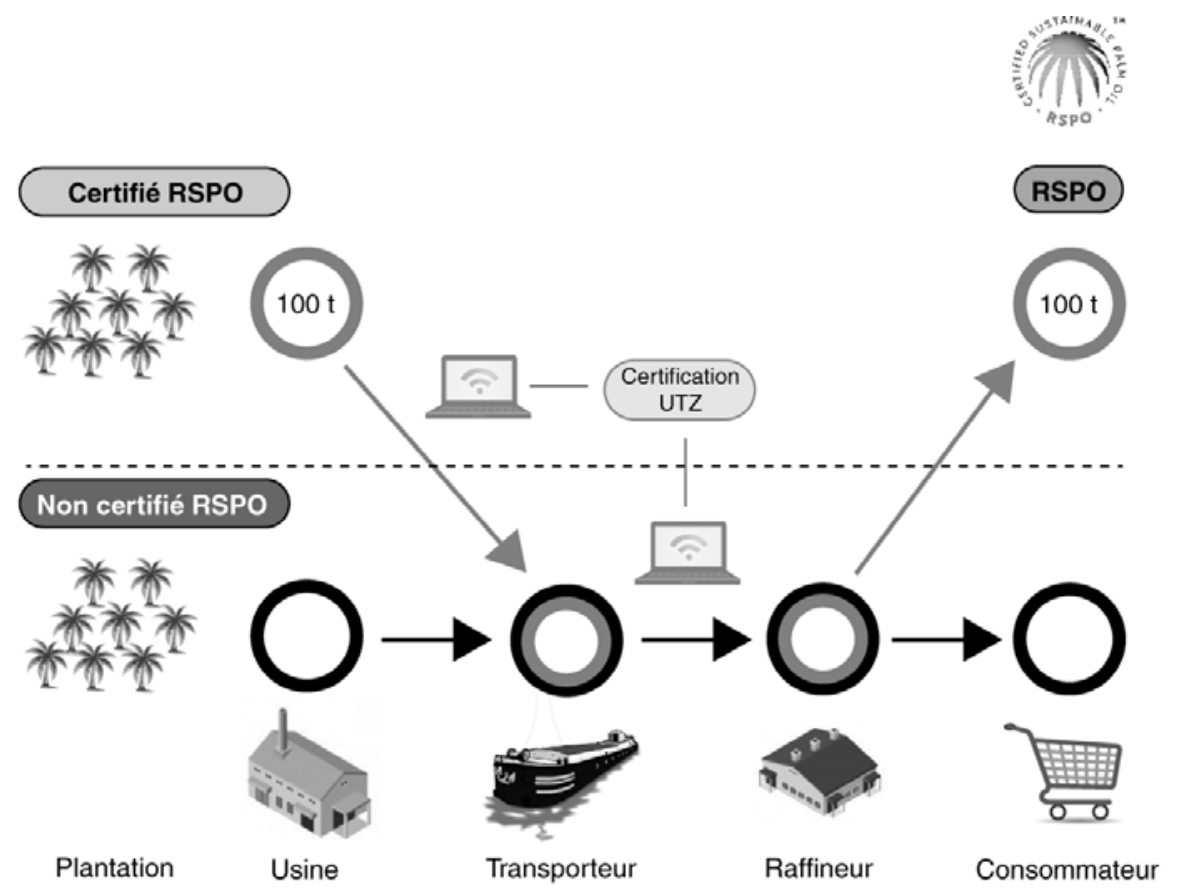

Figure 12. RSPO certification, mass balance.

\section{Segregated}

This model, approved by UTZ Certified, ensures that CSPO palm oil and its byproducts, delivered to the end user, come uniquely from RSPO certified sources. It authorizes the mixing of CSPO oil from several sources providing they are all certified. This type of segregated supply chain guarantees that $100 \%$ of the physical product comes from certified plantations and industrial facilities. However, the oil itself will not come from a single source.

\section{Wording of label}

'Certified — This product contains certified sustainable palm oil, www.rspo.info' 


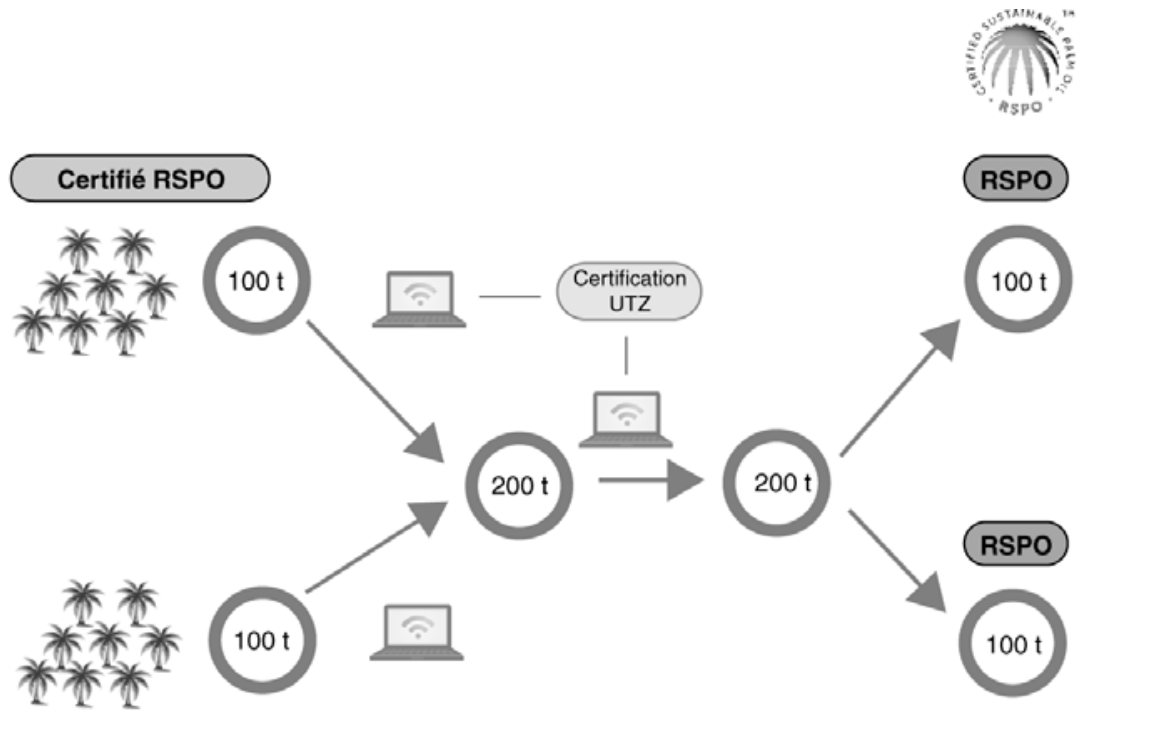

\section{Non certifié RSPO}
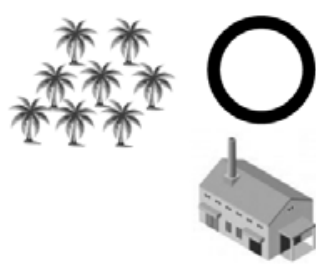

Plantation

Usine

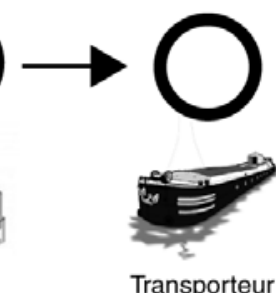

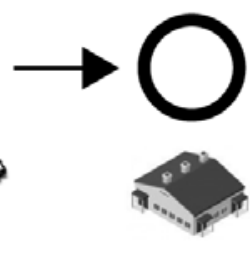

Raffineur

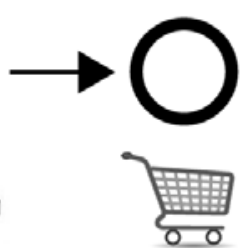

Consommateur

Figure 13. RSPO certification, segregation.

\section{Identity preserved}

The identity preserved supply model ensures that certified palm oil and its byproducts, delivered to the end user, come from a single, identifiable oil mill and supply base and that they remain physically isolated from other sources of palm oil throughout the supply chain (including other CSPO sources). This scheme requires the producer, transporter, refiner and supply chain to maintain complete and total separation as well as traceability from place of production to end user. The latter is guaranteed that $100 \%$ of the palm oil physically received comes from a unique, identifiable, certified RSPO source.

\section{Wording of label}

'Certified — This product contains certified sustainable palm oil, www.rspo.info' 


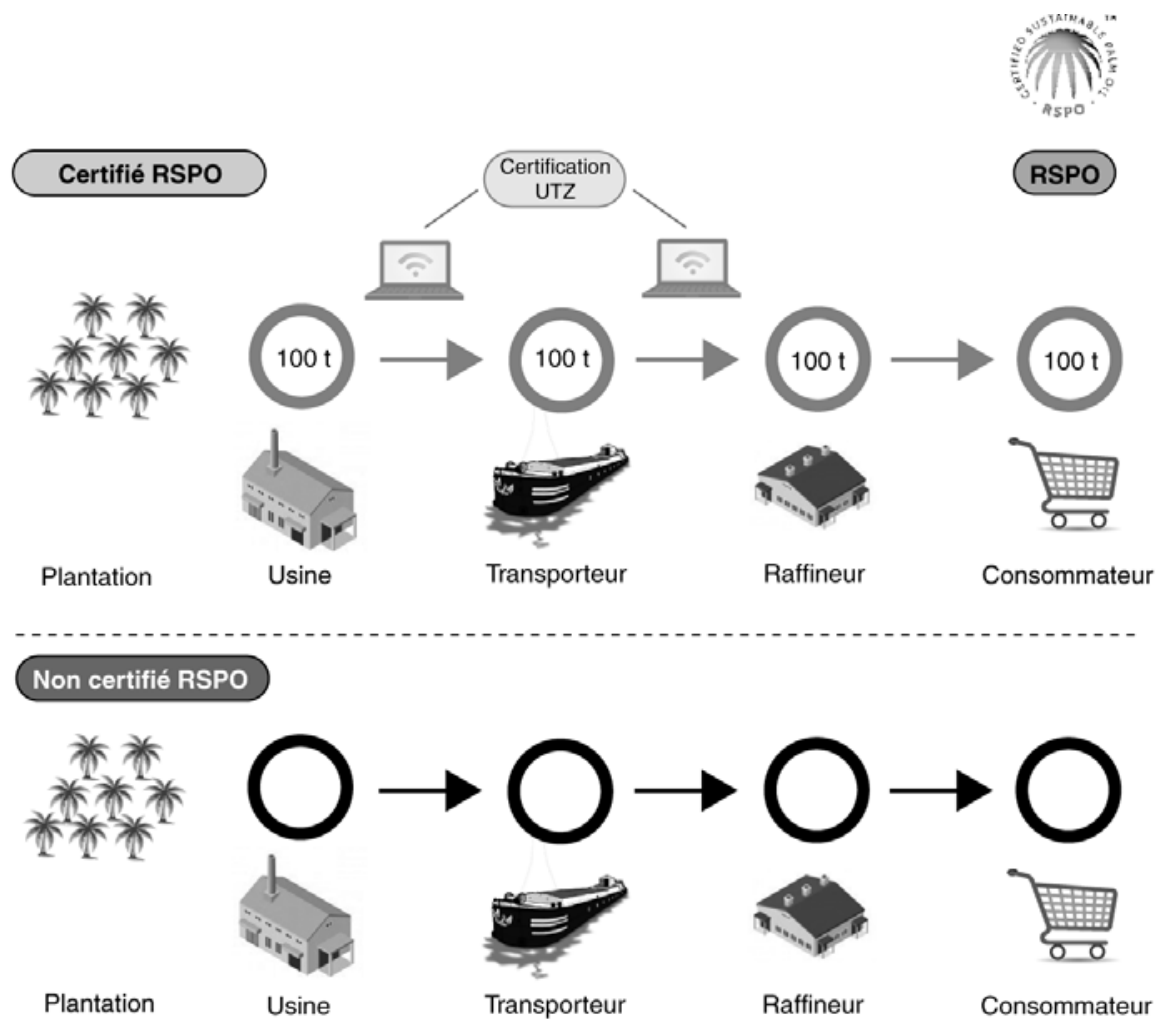

Figure 14. RSPO certification, identity preserved.

The indirect effects of RSPO certification have recently been analyzed by WWF. (WWF 2012a). This study clearly shows the benefits of RSPO certification for planters, over and above the simple premium on the purchase price of certified oil. In fact, the current premium (US\$0.6 per tonne of oil) paid to the producer is quite insufficient to cover costs of certification which come to US\$2-40 per hectare, (about US\$0.5-10 per tonne.) However, the indirect benefits are very important in terms of organization of the company or cooperative, standardization of procedures, traceability of products and inputs, safety at work and social protection, amongst many other effects. For cooperatives which bring together smallholders, the gains in productivity following certification can be considerable (WWF 2012a).

The question of financing RSPO certification for smallholders plantations is more topical than ever; it is the focus of the ongoing review of the certification principles and criteria. The first experiment, carried out in Thailand (FAO 2012), produced very high costs of certification (US\$28 per hectare) and a premium for 
planters that was not sufficiently motivating (US\$0.0003 per kilogram of fruit harvested). These cooperatives were only certified thanks to the intervention of outside donors.

In spite of its recognized weaknesses, which are shared by a number of private multi-stakeholder initiatives which pre-date it, the RSPO has the great merit of setting out the basis for constructive dialogue within the industry. It offers imperfect but useful tools for raising the moral standard of the palm oil production chain and for steering it towards greater sustainability.

These certification tools are still basically qualitative and, if they are to gain credibility, must be refined and consolidated on the basis of proven scientific results, which are shared and recognized. Much of the collaborative research underway on the oil palm is designed to identify suitable solid indicators of sustainability.

At the end of 2012, RSPO launched an in-depth revision of its principles and criteria, which had become necessary to adapt to the specific constraints of smallholders. It became pressing to do more to involve stakeholders who were still underrepresented, such as governments, importers and processors from the South (China, India, Pakistan), smallholders, universities and national and international research center. An improved system of certification should also ensure that governments are given an important role. Because, when all is said and done, it is they who are in charge of legislating and applying the laws which convey the criteria of sustainability in each country (forest moratoria, compulsory standards, land concessions and community rights).

The recent emergence of compulsory national standards (Indonesian Sustainable Palm Oil and Malaysian Sustainable Palm Oil) is a sign of the successful appropriation of the idea of certification but also of the need to move on to compulsory national rules instead of voluntary international ones.

Investors also have a key role to play (WWF 2012b) in the sustainable development of the sector, by making their support subject to the inclusion of issues of governance and compliance with social and environmental standards and RSPO certification, on the part of their beneficiaries. 


\section{Beyond controversy: What role for research?}

Cultivation of a perennial plant like oil palm requires very long-term investment in scientific research. As there is no international research center devoted to oil palm, in the past research was carried out in national agronomic research institutes and by the plantation companies themselves.

There has been a considerable increase in the number of scientific publications on the oil palm and palm oil over recent decades (Figure 15), demonstrating growing interest on the part of the scientific community.

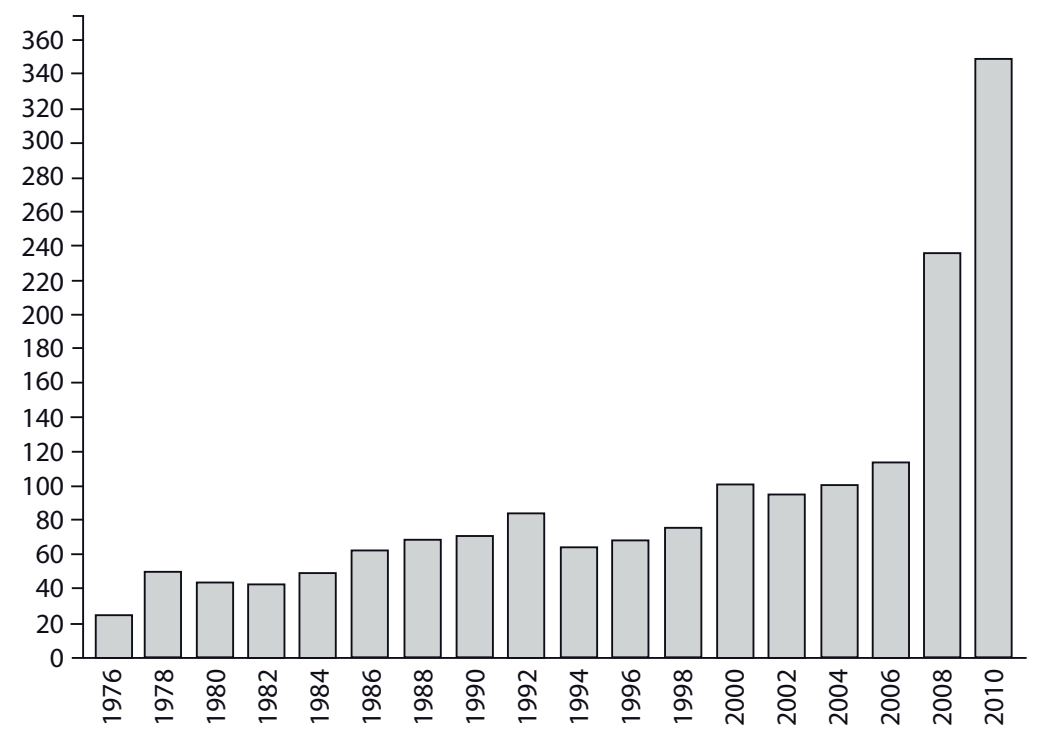

Figure 15. Scientific publications devoted to oil palms and palm oil from 1978 to 2010. Source: ISI Web of Sciences.

This interest is no doubt stimulated by the emergence of complex interwoven issues linked to the rapid expansion of the palm crop. The economic, environmental and social consequences of this expansion pose new questions to research, brought up by new actors in the sector (NGOs, certification bodies, development agencies and responsible investors). This research activity is funded through bilateral collaboration between plantation companies and universities or research institutes, and large-scale multidisciplinary projects. 
Genetic improvement of oil palm is an ongoing process, initiated more than 50 years ago and involving thousands of hectares devoted to genetic tests throughout the world, the results of which are shared in a network. Genetic research now uses biotechnologies (micro-propagation, marker-assisted selection, genome mapping and gene discovery), and this accelerates genetic progress and its dissemination amongst end users.

Identifying ideotypes (the ideal oil palm) is a long-term goal, which raises the often divergent concerns of the various actors in the sector. Family farmers seek palm trees which produce large bunches because they are paid according to the weight of fresh fruit. Factory owners in charge of the production of oil want a higher rate of extraction from fruit. Processors, under pressure from consumers, are after a palm oil with a better fatty acid balance — richer in oleic acid and lower in palmitic acid. All these different properties must then be translated into heritable traits through the process of genetic improvement. This varietal improvement does not involve genetic modification; genetic transformation is particularly delicate in monocotyledons such as palms. Although the technical feasibility of genetic engineering for oil palm was proved in Malaysia nearly 20 years ago, to date we do not have a simple agronomic trait we could improve in this way. Speed of growth, oil yield or fatty acid composition are all multigenic traits and heritable to different degrees; to generate useful GM crops, we look for characteristics governed by one or just a handful of genes. In addition, palm oil is on the point of becoming the only major non-GM oil on the market, a commercial argument which is making its weight felt.

In the context of current and future climate change, growers hope to develop a reliable tool to forecast yield. Efforts to model the impact of global climate change (including El Niño and La Niña episodes) on plantation yield require meteorological data and calculations of yield in different agro-ecological environments and over long time frames (several decades). This very long-term research relies on bilateral North-South networks and partnerships and actively involved public-private actors.

The criteria for evaluating and certifying palm oil plantations must be robust and acceptable to all stakeholders. These criteria should be based on simple indicators with a solid scientific foundation. The principles and criteria for sustainability certification rarely refer to numerical data: Large scale multidisciplinary studies must be carried out to fill this knowledge gap.

Over the last decade, several large-scale collaborative projects linking plantation companies, NGOs and academic institutions have finally got off the ground and started work on decoding the biological, agro-ecological and social bases of sustainability in oil palm cultivation.

The Sensor (Socially and Environmentally Sustainable Oil Palm Research) project, coordinated in Southeast Asia by the Royal Society of London is developing a 
multidisciplinary approach to the validation and development of RSPO principles and criteria. The project brings together the European universities of York, Wageningen, Leeds, Lancaster and Swansea and tackles five major topics: water and soil, air quality and greenhouse gas, biodiversity, zones of high conservation value, and participatory rights and procedures and standard of living. Its main objectives are to build up confidence in CSPO certified palm oil amongst users, investors and the general public, guarantee that the efforts and investments put into sustainable practices are profitable and that these practices are recognized in the market and, finally, to protect the environment and society in the long term through rigorous evaluation and the development of practices capable of delivering proven results.

The Safe (Stability of Altered Forest Environment) project is being carried out on the island of Borneo over a period of 10 years (2010-2020), by the Royal Society of London and the Sime Darby Foundation, with a budget of $€ 7.3$ million. This is an ecological research project designed to quantify the impact of establishing oil palm plantations on the biodiversity of adjacent forests. It aims to identify situations which minimize impact on biodiversity and optimize ecosystem services. Research programs look at the diversity of flora and fauna, water and soil, the carbon cycle, nutrients and the microclimate in forest blocks of 1,10 and 100 hectares, set aside within an oil palm plantation. The study zones are set up in new plantations, productive plantations, zones previously deforested and plots of primary forest.

CIRAD, INRA, CENIPALMA, PT Smart and NBPOL ${ }^{11}$ set up the PalmiNet network in order to develop shared indicators on the social and environmental impact of the oil palm crop. The idea is to promote the use of indicators by actors in the sector, share research efforts and feedback, facilitate the development of tools and indicators, encourage new forms of collaboration and multidisciplinary research and disseminate results among a wide audience of potential users.

On the interface between agronomy and social sciences, the Sustainable Palm Oil Production project (SPOP), supported by the French National Research Agency (Agence Nationale de la Recherche) aims to verify the sustainability of current systems or to propose new sustainable systems. It involves actors in the process through participatory methods such as multi-agent modelling.

The local interpretation and practical application of RSPO certification principles and criteria raise numerous questions for research in the field of human and social science. For example, the relationship between private international standards

11 CIRAD: Centre for International Cooperation in Agronomic Research for Development (Centre de coopération internationale en recherche agronomique pour le développement) (France); INRA: National Institute for Agronomic Research (Institut national de recherche agronomique) (France); CENIPALMA: National Centre for Oil Palm Research in Colombia; PT Smart: Indonesian plantation company; NBPOL: New Britain Palm Oil Ltd, plantation company, Papua New Guinea. 
(for example, RSPO criteria) and public regulations (as in national legislation drawn up in Malaysia and Indonesia) is now the subject of research. The current certification process is an example of the privatization of global environmental governance; it raises questions as to the role of private actors (agro-industries and NGOs) in environmental regulation. The French project PRIGOUE, bringing together CIRAD, INRA, the National Centre for Scientific Research (Centre National de Recherche Scientifique - CNRS) and the Institute for Science and Industry of Living things and the Environment (Institut des Sciences et Industries du Vivant et de l'Environnement - AgroParistech), aims to answer these questions.

The impact of certification itself will eventually be the subject of research; it must be quantified and interpreted using the precise shared indicators which are currently the subject of scientific study. 


\section{Conclusion}

When properly planned by local or regional governments, the development of oil palm plantations leads to rapid economic development in the regions concerned and a significant decline in rural poverty. Poorly managed, the extension of plantations may result in the disappearance of high conservation value forests and have adverse impact on local people and indigenous communities.

The establishment of new plantation projects, especially in Africa, offers governments and all stakeholders a unique opportunity to develop a joint strategy for steering the rapid expansion and sustainable development of the sector. All actors (governments, companies, national center for agronomic research, local communities and national and international NGOs) must join together to draw up a preventive strategy and establish the means to oversee its implementation.

This consultation must start from the international certification standards drawn up by IFC and RSPO which constitute an internationally recognized basis on which to work. International standards are available to support this process in terms of governance and quality control (ISO 9000), conservation of the environment (ISO 14000) or social responsibility (ISO 26000).

In future, any strategy for sustainable expansion of the palm oil sector must include:

1. Ecological intensification of existing plantations with the dissemination of selected plant material, well-planned fertilization and recycling of effluents

2. Conservation of biodiversity and of permanent forest reserves, with priority given to the development of zones already deforested or degraded

3. Supervized application of RSPO Principles and Criteria, interpreted in the light of local constraints and integrated into national policies and regulations

4. Integration of smallholders in the development of agro-industrial complexes, either through the establishment of production contracts or by measures to support family farming (such as supply of selected plants and fertilizers, microcredit, technical management and training)

5. Respect for the rights of indigenous peoples and local communities, by obtaining their Free, Prior and Informed Consent (FPIC) and open communication about any development of new plantations

6. Study of land rights and the land register when this exists, and compliance with regulations on the acquisition of land

7. Provision to ensure donors and international NGOs give the oil palm crop a primary role in the eradication of poverty in tropical countries. 
In less than a century, the oil palm has grown from the position of a minor subsistence crop in Africa to one of the world's major agricultural crops. This spectacular evolution has profoundly modified landscapes and livelihoods under the tropics. Driven by world demand and the desire for development in emerging and less advanced countries the trend is not about to be reversed.

It is no longer a question of halting the expansion of the oil palm but of finding a smart way to manage it. All stakeholders should take immediate steps to shape this development and anticipate its impact in terms of biodiversity, greenhouse gas emissions and effective development of local peoples. 


\section{References}

Angerand S. 2011. Arnaque à l'huile de palme durable : 12 questions pour comprendre les enjeux. Accessed April 2013. www.amisdelaterre.org/ IMG/ pdf/rapport_arnaque_huile_de_palme_durable_mai_2011.pdf

ANSES 2011. Opinion of the French Food Safety Agency on the update of French population reference intakes (ANCs) for fatty acids. AFSSA- Request no. 2006-SA-0359. https://www.anses.fr/sites/default/files/documents/ NUT2006sa0359EN.pdf

Bakoume C. 2006. Sustainable development of oil palm in Africa: smallholders' sector. International Planters' Conference, Kuala Lumpur, 26-28 June 2006.

Berger J. 1995. The oils war: opinions and nutrition. OCL, Oléagineux, Corps gras, Lipides. 2 (3): 200-203.

Bissonnette J. 2012. Envisioning agribusiness: land, labour and value in a time of oil palm expansion in Indonesia. PhD thesis. Toronto: Department of Geography, University of Toronto.

Caliman J.-P. 2011. Palmier à huile : le management environnemental des plantations. Dossier Biodiversité et cultures végétales (approches), économie - développement. OCL, Oléagineux, corps gras, lipides 18(3):123-131.

Carlson KM et al. 2012. Committed carbon emissions, deforestation, and community land conversion from oil palm plantation expansion in West Kalimantan, Indonesia. PNAS 109(19):7559-7564.

Chowdhury $\mathrm{R}$ et al. 2014. Association of dietary, circulating, and supplement fatty acids with coronary risk: A systematic review and meta-analysis. Annals of Internal Medicine. 160(6):398-406.

Corley RHV. 2009. How much palm oil do we need? Environmental Science \& Policy, 12:134-139.

Cramb R. and Curry GN. 2012. Oil palm and rural livelihoods in the AsiaPacific region: An overview. Asia Pacific Viewpoint 53(3):223-239.

De Lacharrière G. 1968. Consensus et Nations Unies. Annuaire français de droit international 14(14):9<en-dash>14. www.persee.fr

Drajat B. 2010. The contribution and challenges of smallholders in the oil palm industry. The Jakarta Post 3 December 2010. http://www.thejakartapost. $\mathrm{com} /$ news/2010/12/03/the-contribution-and-challenges-smallholders-oilpalm-industry.html

FAO 2010. Global Forest Resources Assessment 2010: Main Report. Rome: FAO.

FAO 2012. Smallholders in global bioenergy value chains and certification: Evidence from three case studies. Accessed August 2013. http://www. fao. org/docrep/015/i2597e/i2597e00.pdf 
Feintrenie L. Chong WK and Levang P. 2010. Why do farmers prefer oil palm? Lessons learnt from Bungo District, Indonesia. Small-scale Forestry, 9:379-396.

Feintrenie, L. and P. Levang 2009. Sumatra's Rubber Agroforests: Advent, Rise and Fall of a Sustainable Cropping System Small-scale Forestry 8(3): 323-335.

FFAS, 2012. L'huile de palme, aspects nutritionnels, sociaux et environnementaux: État des lieux du Fonds français pour l'alimentation et la santé. Accessed August 2013. http://www.alimentation-sante.org/wp content/ uploads/2012/11/ Etatdeslieux_HdP_1112.pdf

Fieldhouse DK. 1978. Unilever Overseas: The Anatomy of a Multi-National, 18951965. London: Croom Helm.

Fournier S, Peter AY, Jannot C, Okounlola-Biaou A and Euloge Pédé 2001. La transformation artisanale de l'huile de palme au Bénin et au Nigeria. Berlin: Cerna, Cirad, Freie Universität Berlin, SRPH.

Friedel, M.-C. 1897. Sur des matières grasses trouvées dans des tombes égyptiennes d'Abydos. Comptes rendus de l'Académie des sciences 24:648-651.

Gouyon, A., H. de Foresta, and P. Levang 1993 Does 'jungle rubber' deserve its name? An analysis of rubber agroforestry systems in southeast Sumatra. Agroforestry Systems 22: 181-206.

Hartley CW-S. 1988. The Oil Palm (Elaeis guineensis Jacq.). Third edition. London: Wiley.

Hoyle D and Levang P. 2012. Le développement du palmier à huile au Cameroun. Working document. Geneva: WWF. Accessed April 2013. awsassets.panda. org/downloads/developpmentpalmie- rhuilecameroun.pdf

Jacquemard JC. 2012. Le palmier à huile. Versailles, France: Quæ Éditions (Agricultures tropicales en poche).

Jannot C. 2014. Les filières oléagineuses en Afrique de L'Ouest et du centre : le grand retour du palmier à huile. Le Demeter2014, pp: 247-312. http://www. clubdemeter.com/pdf/ledemeter/2014/les_filieres_oleagineuses_en_afrique_ de_1_ouest_et_centrale_le_grand_retour_du_palmier_a_huile.pdf

Kiple K-F Ornelas K. (eds). 2000. The Cambridge World History of Food. Cambridge, UK: Cambridge University Press.

Laurence W-F et al. 2010. Improving the performance of the Roundtable on Sustainable Palm Oil for Nature Conservation. Conservation Biology 24(2):1523-1739.

Leplae E. 1939. Le palmier à huile en Afrique : son exploitation au Congo belge et en Extrême-Orient. Volume 7. Brussels: Hayez.

Levang P. 1997. La terre d'en face. La transmigration en Indonésie. Paris: Orstom.

Maley J. 2003. Synthèse sur l'histoire de la végétation et du climat en Afrique centrale au cours du Quaternaire récent. In: Froment A and Guffroy J (eds.). Peuplements anciens et actuels des forêts tropicales : Actes du séminaire-atelier. Paris: IRD, pp. 53-75.

McCarthy J. 2012. Certifying in contested spaces: private regulation in Indonesian forestry and palm oil. Third World Quarterly 33(10)1871-1888. 
Mesa Dishington J. 1998. Un modelo para el desarrollo competitivo de la palma de aceite en Colombia. Palmas 19:18-28.

Norman B. 2010. Greenpalm: Une approche innovante pour l'huile de palme durable. <www.greenpalm.org/upload/files/18/ GreenPalm_4pp_French. pdf, consulted June 2013.

Peters, C., A. Gentry, and R. Mendelsohn. 1989 Valuation of an Amazonian rain forest. Nature 339: 655-656.

Rafflegeau S. 2008. Dynamique d'implantation et conduite tech-nique des plantations villageoises de palmier à huile au Cameroun : facteurs limitants et raisons des pratiques. Agronomy thesis. Paris: AgroParisTech.

Siri-Tarino PW, Sun Qi FB, Hu RM and Kraus 2010. Meta-analysis of prospective cohort studies evaluating the association of saturated fat with cardiovascular disease. Am J Clin Nutr 91(3):535-546.

Swaine M-D. 1992. Characteristics of dry forest in West Africa and the influence of fire. J. Vegetation Sc. 3:365-374.

Teoh C-H. 2010. Key Sustainability Issues in the Palm Oil Sector. Washington, DC: International Finance Corporation, World Bank Group, 53 p. Accessed April 2013. www.ifc.org/ifcext/ agriconsultation.nsf/AttachmentsByTitle/ Discussion+Paper_French/\$FILE/Discussion+Paper_French_FINAL.pdf

WWF. 2011. Conservation, forêts. Huile de palme : de la déforestation à la nécessaire durabilité. Paris: WWF 40 p. Accessed April 2013. wwf.fr/media/files/ rapport-huile-de-palme-2011, consulted April 2013.

WWF. 2012a. Sustainability in palm oil production: analysis of incremental financial costs and benefits of RSPO compliance. Gland, Switzerland: WWF, 60 p. Accessed June 2013. assets.worldwildlife.org/publications/350/ files/original/Profitability_and_Sustainability_in_Palm_ Oil_Production. pdf?1345734683

WWF. 2012b. Palm oil investor industry, investor guidance on palm oil: the role of investors in supporting the development of sustainable palm oil industry. Gland, Switzerland: WWF, 24 p. Accessed April 2013. awsassets.panda.org/ downloads/wwf_palmoil_investorreview.pdf 


\section{Useful Internet sites}

Roundtable on Sustainable Palm Oil: www.rspo.org.

Roundtable on Responsible Soy Association: www.responsiblesoy.org. Forest Stewardship Council: www.fsc.org.

Stability of Altered Forest Ecosystems Project: www.safeproject.net.

Palm Indicators Network PalmiNet: community.plantnet-project.org/pg/ groups $/ 2879 /$ palminet.

Greenpalm: www.greenpalm.org.

Sustainable Development of Palm Oil Production (SPOP): www.agencenationale-recherche.fr/programmes-de-recherche/.../fiche-projetagrobiosphere/?tx_lwmsuivibilan_pi2 \%5

The Socially and Environmentally Sustainable Oil Palm Research Program (Sensor): www.searrp.org/sensor. 
The rapid development of oil palm cultivation feeds many social issues such as biodiversity, deforestation, food habits or ethical investments. How can this palm be viewed as a 'miracle plant' by both the agro-food industry in the North and farmers in the tropical zone, but a serious ecological threat by non-governmental organizations (NGOs) campaigning for the environment or rights of local indigenous peoples?

In the present book the authors - a biologist and an agricultural economist- describe a global and complex tropical sector, for which the interests of the many different stakeholders are often antagonistic. Oil palm has become emblematic of recent changes in North-South relationship in agricultural development. Indeed, palm oil is produced and consumed in the South; its trade is driven by emerging countries, although the major part of its transformations is made in the North that still hosts the largest multinational agro industries. It is also in the North that the sector is challenged on ethical and environmental issues.

Public controversy over palm oil is often opinionated and it is fed by definitive and sometimes exaggerated statements.

Researchers are conveying a more nuanced speech, which is supported by scientific data and a shared field experience. Their work helps in building a more balanced view, moving attention to the South, the region of exclusive production and major consumption of palm oil.

\begin{tabular}{|c|c|c|}
\hline CGIAR & $\begin{array}{l}\text { RESEARCH } \\
\text { PROGRAM on } \\
\text { Forests, Trees an } \\
\text { Agroforestry }\end{array}$ & $\begin{array}{l}\text { This research was carried out by CIFOR as part of the CGIAR Research Program } \\
\text { on Forests, Trees and Agroforestry (CRP-FTA). This collaborative program aims } \\
\text { to enhance the management and use of forests, agroforestry and tree genetic } \\
\text { resources across the landscape from forests to farms. CIFOR leads CRP-FTA in } \\
\text { partnership with Bioversity International, CATIE, CIRAD, the International Center } \\
\text { for Tropical Agriculture and the World Agroforestry Centre. }\end{array}$ \\
\hline
\end{tabular}

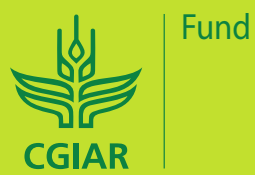

